DEPARTMENT OF THE INTERIOR

U. S. GEOLOGICAL SURVEY

\title{
DEVELOPMENT OF RAINFALL WARNING THRESHOLDS FOR DEBRIS FLOWS IN THE HONOLULU DISTRICT, OAHU
}

\author{
by Raymond C. Wilson ${ }^{1}$, Jill D. Torikai ${ }^{2}$, and Stephen D. Ellen ${ }^{1}$
}

OPEN-FILE REPORT 92-521

Prepared in cooperation with the CITY AND COUNTY OF HONOLULU, DEPARTMENT OF PUBLIC WORKS

This report is preliminary and has not been reviewed for conformity with U.S. Geological Survey editorial standards or with the North American Stratigraphic Code. Any use of trade, product or firm names is for descriptive purposes only and does not imply endorsement by the U.S. Govemment.

${ }^{1}$ Menlo Park, CA 94025

${ }^{2}$ Honolulu, HI 96813

September 1992 


\title{
Development of Rainfall Warning Thresholds for Debris Flows in the Honolulu District, Oahu, Hawaii
}

\author{
by Raymond C. Wilson, Jill D. Torikai, and Stephen D. Ellen
}

\begin{abstract}
The goal of this investigation is to determine threshold levels of intensity and duration of storm rainfall necessary to initiate debris flows on the steep hillslopes of the Honolulu District. These rainfall thresholds could find a future application in a debris-flow warning system for Honolulu, similar to a prototype warning system developed several years ago and now operating in the San Francisco Bay region in northern California.

Previous studies suggest that debris flows are triggered when heavy rainfall, infiltrating into the shallow subsurface, becomes impounded and creates elevated pore pressures that weaken the slope materials. Based on this idea, a simple numerical model was developed to study the interaction between heavy rainfall and pore-pressures on steep hillslopes. In order to calibrate this model to the ground conditions within the Honolulu District, detailed recordings of both rainfall and shallow pore pressures have been made at two remote sites on steep hillslopes. These recordings confirm the presence of temporarily elevated pore pressures in response to heavy rainfall and show a correlation between the peak pore-
\end{abstract}


pressure response and the maximum amounts of rainfall recorded for periods of 3 to 6 hours.

An extensive historical data base of rainfall amounts and debris flow occurrences has been compiled for 17 large storms in the Honolulu District over the past 33 years. Plots of these historical data display well defined, lower bound relationships between the number of debris flows reported during storms and the peak rainfalls recorded over periods of 1 to 6 hours. Two threshold levels were derived from these lower bound relations: a "safety" threshold below which the likelihood of damaging debris flows is very low, and an "abundant" threshold level above which rainfall is likely to cause many debris flows and thus pose a hazard to life and property.

\section{Introduction:}

This report presents the results of a study undertaken by the U. S. Geological Survey (USGS), in cooperation with the City and County of Honolulu Department of Public Works to develop rainfall warning thresholds for debris flows in the Honolulu District of Oahu. Such thresholds are a necessary step in the development of a real-time debrisflow warning system. The report describes the results of our several approaches to the problem, as well as the thresholds obtained and their potential use.

\section{Physical and Historical Setting:}

The Honolulu District (fig. 1) combines several of the essential components for debris-flow hazards: steep hillsides, heavy rainfall, and 
strong pressure for residential development in upland areas. Debris flows are dangerous because they occur suddenly and move rapidly by flowing or avalanching down hillslopes and channels. They generally occur during or immediately after severe rainfall. Their nature in the Honolulu area, where they have been called soil avalanches, has been described by Wentworth (1943), Scott (1969), and Scott and Street (1976).

The hazards presented by debris flows have been described by Campbell (1975) and by Ellen and Wieczorek (1988). Debris flows can cause damage either directly, by colliding with man-made structures, or indirectly, by plugging drainage systems so that flood waters are diverted out of the channels. Debris flows also can sever or cover roads, blocking access to (or egress from) neighborhoods, and thus interfere with emergency operations and evacuations.

The hazards of debris flows in the Honolulu District were brought to the public's attention during the New Year's Eve storm of 1987-1988 (State of Hawaii, 1988; Dracup and others, 1991). Most of the damage occurred in the eastern part of the Honolulu District. Debris flows directly impacted several homes in Kuliouou and Hahaione valleys. Debris from a number of landslides clogged a drainage structure, and caused severe flooding in Hahaione Valley. The storm also triggered a large landslide high in the Kupaua valley that sent tons of mud, rock, and other debris downstream into lower Niu Valley, obstructing drainage channels and flooding a number of homes and a shopping center (State of Hawaii, 1988). Fortunately, no lives were lost, and the damage to private property was light, in view of the severity of the storm and the hundreds of debris flows it produced (Ellen and others, 1991). Total damage from 
the storm was nevertheless sufficient to warrant a federal disaster declaration (Interagency Flood Hazard Mitigation Team, 1988).

As described below, our study indicates that the debris flows triggered by the New Year's Eve storm were not a unique occurrence in the history of Honolulu. At least 15 storms during the past 30 years have triggered debris flows that caused sufficient damage or inconvenience to either have complaints filed with the Oahu Civil Defense Agency (OCDA) or be mentioned in newspaper accounts of the storms (table 1). In addition, careful mapping of debris-flow features visible on aerial photographs taken between 1940 and 1989 indicates that numerous debris flows occurred in several different episodes during this time period in several different areas of the Koolau Range (D. M. Peterson, unpub. data, 1991). Most of these debris flows caused relatively little direct property damage because they occurred in undeveloped or relatively inaccessible upland areas. However, some of the areas affected by past debris flows have since been developed, and if development continues in these upland areas, the impacts from debris flows in future storms could become even more frequent and costly.

\section{Debris-Flow Warning Systems:}

One way of lessening the hazards from debris flows would be to develop a debris-flow warning system capable of rapidly responding to approaching or developing rainstorms. This system would determine when rainfall conditions were approaching sufficient severity to trigger debris flows and provide public warnings so that steps could be taken to minimize risk to life and property. Such a system was developed for the 
San Francisco Bay Region and has been in operation since 1986 (Keefer and others, 1987).

The development of a real-time warning system for debris flows requires several elements: (1) reliable meteorological systems for forecasting severe rainstorms and for observing rainfall in various parts of the area as it occurs, that is, on a real-time* basis; (2) a knowledge of the hydrologic conditions that trigger debris flows and the rainfall intensities and durations necessary to produce them; (3) a procedure for distributing warnings to the public and responsible agencies; and, (4) procedures for actions to be taken in the event of a warning, such as mobilization of emergency response teams and evacuations of threatened neighborhoods. This report addresses the second requirement by developing rainfall warning thresholds for debris flows within the Honolulu District.

In the San Francisco Bay region, the National Weather Service (NWS) handles the forecasting, sponsors a network of radio-telemetering rain gages operated by several public agencies, and broadcasts warnings over the NWS radio system to emergency services, local agencies, news media, and the general public. The USGS has developed the rainfall warning thresholds, advises the NWS on when to issue the warnings, and documents the occurrence of debris flows and the damage that results. The State and County Offices of Emergency Services, along with other local agencies, are responsible for evacuations, rescue operations, and emergency repairs to roads and drainage systems.

\footnotetext{
* "Real-time" means without delay, at the instant of occurrence. Many systems for rainfall measurement require manual retrieval of data stored over periods of days or weeks.
} 
Practical debris-flow warning systems have become possible in recent years because of several technological advances: (a) Weather satellites provide visual imagery of major weather systems and allow these systems to be tracked over thousands of miles. (b) Radio-telemetered tipping-bucket rain gages allow real-time monitoring of actual rainfall conditions at numerous locations scattered over a wide area. (c) Digital micro-computers have been developed that are inexpensive and durable enough to be dedicated solely to the task of gathering and processing weather information. These micro-computers are capable of automatically monitoring, and analyzing data from dozens of radiotelemetered rain gages, and then, within a few seconds of acquisition, providing the user with simple, easily interpreted displays of the information. These developments, along with associated improvements in weather radar systems, are leading to the emergence of a new style of weather forecasting termed, "nowcasting" (Browning and Collier, 1989).

These technological advances provide the user with access to rainfall and other weather data with unprecedented temporal and spatial coverage. Large weather systems capable of producing the severe rainfall necessary to trigger debris flows can be observed and tracked over distances of thousands of miles, even over open ocean. Data on actual rainfall levels over areas of hundreds of square miles can be accessed nearly instantaneously and monitored continuously. If such a nowcasting system were developed for Oahu, then the probabilities of debris-flow hazards could be evaluated by comparing the forecast and observed rainfall levels to the rainfall warning thresholds described in this paper, so that decisions about response actions could be made before the storm conditions actually reached the critical level. 


\section{Organization of the Report:}

In the following sections, we first describe the mechanism by which heavy rainfall triggers debris flows by creating locally-elevated porepressures within the hillslope soils. We then describe a mathematical model of this mechanism that allows us to study the link between heavy rainfall and shallow pore-pressure response within the hillslope. The next section outlines our measurements of rainfall and shallow pore-pressures at two remote sites in the Koolau Range over the past two years, and our attempts to use these data to calibrate our theoretical model for actual conditions on Oahu. The following section summarizes our collection of historical data on rainfall and the occurrence of debris flows, and our use of these data to constrain rainfall warning thresholds for debris flows in the Honolulu District. The final sections describe the possible utilization of these rainfall warning thresholds and offer some additional suggestions for implementation of a real-time warning system for debris flows in Honolulu.

\section{Acknowledgments}

We thank Sam Callejo and his staff of the Department of Public Works, City and County of Honolulu for their generous support and assistance during this cooperative investigation. The assistance of the Oahu Civil Defense Agency and the Honolulu Board of Water Supply during data collection are greatly appreciated. Mr. Paul Haraguchi, of the Hawaii State Department of Land and Natural Resources, provided assistance with locating data on historical rainfall events. The Bernice 
Bishop Estate gave permission to site the Kaluanui Ridge monitoring station on their property.

\section{Theory of Debris-Flow Initiation:}

\section{The Campbell Model:}

The theoretical basis for our studies rests on Campbell's (1975) conceptual model of the mechanism by which rainfall triggers debris flows, developed from his studies of the initiation of debris flows by heavy rainfall in the Los Angeles metropolitan area. Campbell's model is illustrated in figure 2, which is a sketch of a cross-section of a steep hillslope being subjected to heavy storm rainfall. The cross-section shows a layer of colluvial soil, a loose mixture of residual soil and weathered bedrock, lying on firm, consolidated bedrock. Campbell stipulated that, prior to the storm, the colluvial soil already contained sufficient moisture to be at field capacity, which is the water content of a soil that is first saturated, then allowed to drain freely by gravity.

Under such conditions, the colluvial soil tends to have a high infiltration coefficient, so that, even in intense rainfall, all or most of the water soaks into the ground. Somewhere in the subsurface, however, such as where the loose colluvial soil rests on more consolidated bedrock, a zone of decreased permeability may be encountered that impedes the rate of water infiltration. If intense rainfall continues, a layer of saturated soil can build up above this less permeable zone, creating what is known as a perched water table. 
With continued heavy rainfall, the layer of saturated colluvial soil becomes thicker, which increases the pressure of the water filling the pore spaces in the soil. This increase in pore pressure lowers the effective overburden stress within the soil and has the effect of decreasing the shear strength of the soil (Terzaghi, 1950). If the slope is steep and the pore pressures increase locally, then the reduction in shear strength may lead to failure of the slope.

The slope failures that lead to most debris flows in Honolulu involve a very thin layer, typically less than $2 \mathrm{~m}$ thick, composed of loose colluvial soils and the uppermost zone of weathered rock that lie above the bedrock (Ellen and others, 1991). As it begins to be deformed during failure, this loose, water-soaked material may undergo a further loss of strength, called "mobilization," (Ellen and Fleming, 1987). This collapse of soil strength may cause a shift in the balance of forces leading to a sharp acceleration of the failure mass. If the failure occurs above a long, steep slope, this acceleration may cause the mobilized mass of soil, rock, and uprooted vegetation, weighing up to many tons, to reach speeds of up to 40 miles per hour, thus building up a great momentum. When such a fast moving, heavy mass collides with a house or other structure downslope, the structure is usually severely damaged or destroyed.

As the debris flow approaches the bottom of the hillslope and the steepness decreases, the mass decelerates and much of the flowing debris, including mud, rocks, trees, and other debris picked up along the flow path, is deposited. This deposited material may block roadways, plug drainages, and cause other problems.

An important aspect of the Campbell model, in the context of developing a warning system, is that the process of debris-flow initiation 
takes place during, or immediately after, severe rainstorms. If sufficient soil moisture (i.e. field capacity) already exists in the hillslope soils from previous rainfall, debris flows can be triggered by intense storm rainfall of only a few hours duration. A more precise understanding of the interactions between severe rainfall, increased pore pressures in shallow soils, and the triggering of slope failures, would greatly facilitate the prediction of debris flows.

\section{The Leaky Barrel Model:}

In an attempt to provide a more quantitative understanding of the interactions between rainfall and high pore pressures in the shallow soils, Wilson (1989) has developed a mathematical simulation of Campbell's conceptual model, based on a simple physical analog, a leaking rain barrel. This "leaky barrel model," illustrated in figure 3, consists of a cylinder, open at the top and closed on the bottom, forming a barrel. The open top reflects an assumption that the infiltration capacity exceeds the highest rainfall intensity likely to be experienced. As rainfall begins, the barrel begins to fill with water. The barrel, however, permits drainage by the faucet shown in figure 3 . The rate of drainage through the faucet is proportional to the water pressure, which in turn is proportional to the depth of water in the barrel. As the barrel fills with rainfall (representing the layer of saturated soil building up in the hillslope), the water pressure increases, thereby increasing the rate of flow from the faucet.

This linkage between drainage rate and water depth in the leaky barrel model simulates the dynamic interaction between rainfall intensity and thickness of the layer of saturated soil in a hillslope. The greater the rainfall intensity, the more water accumulates in the saturated layer; but 
the more water accumulates, the faster the water drains away. If rain fell at a constant intensity, the model would eventually reach a state of dynamic equilibrium in which the rate of drainage balances the rate of rainfall (fig. 4A). In real storms, however, the rainfall intensity is rarely constant, but increases and decreases, thereby producing a corresponding rise and fall in the thickness of the zone of saturation in the hillslope (fig. 4B).

The interaction between incident rainfall and the depth of water retained in the leaky barrel model (fig. 3) can be described with a firstorder differential equation (Wilson, 1989):

$$
\frac{d Z}{d t}=I(t)-K_{d} Z
$$

where $\mathrm{Z}$ is the depth of water in barrel above the faucet, $I(t)$ is the rainfall intensity (depth/time), and $\mathrm{K}_{\mathrm{d}}$ is a proportionality constant called the "drainage coefficient," with units of (1/time).

Another way of describing the relationship between the drainage rate and the amount of water retained within the zone of saturation is in terms of a "drainage half-life," $\left(\mathrm{T}_{1 / 2}\right)$. Equation 1 predicts that, after the rainfall ceases, there is a constant time-period in which half of the water in the barrel drains away (Wilson, 1989), such that:

$$
\mathrm{T}_{1 / 2}=\frac{\ln (2)}{\mathrm{K}_{\mathrm{d}}}
$$

Measurements of shallow pore pressures in a hillslope near La Honda, California, have suggested that, at the point of measurement, the soil 
exhibits an approximately constant time period over which half of the pore pressure dissipates (Wilson, 1989). Recent measurements of rainfall and pore pressures on steep hillslopes in the Honolulu District, described below, indicate a similar behavior.

Several important aspects link the idealized leaky-barrel model to actual conditions in hillslope soils. The amount of rain water retained in the barrel represents the rainfall retained within the zone of saturated soil in the hillslope. A network of piezometers, instruments that measure positive pore-pressures in the soil, can be used to estimate the thickness of the zone of saturation in the soil in an actual hillslope. The drainage coefficient, $K_{d}$, links the drainage rate to the pore pressures within the soil and, thereby, to the thickness of the zone of saturation.

Another important factor is that the faucet is part-way up the side of the barrel in figure 3. The water in the part of the barrel below the faucet represents the moisture in a soil at field capacity. This moisture does not drain away gravitationally and can be removed only by evaporation and transpiration. This is also approximately the amount of water that must be added to overcome the moisture deficit in dry soils that produces negative pore-pressures, known as soil suctions. This moisture deficit must be satisfied before positive pore pressures can form.

This moisture deficit, or "antecedent moisture," is significant in the San Francisco Bay region, which has a Mediterranean climate characterized by dry summers and wet winters. At the beginning of the wet season the moisture deficit is large, between 8 and 14 inches of rain, and must be overcome before even heavy rainfall can produce positive pore pressures. The seasonal variations in rainfall are not so extreme in Hawaii, so this factor has not been as great a concern for this study. 
A third important factor is the "effective porosity" $\left(\mathrm{N}_{\mathrm{cf}}\right)$ of the soil. In figure 3 , the barrel is empty except for the rainwater. In a real soil, of course, much of the volume is taken up with solid particles of soil. The water within the zone of saturation occupies only the pore spaces between soil particles. When the soil is at field capacity, a certain volume of water is attached to the solid soil grains by capillary attraction and chemical bonding, which further reduces the pore volume. Thus, the height of the zone of saturation is not only related to the volume of retained rainfall, but also to the effective porosity of the soil. For example, an inch of precipitation retained in a soil with an $\mathrm{N}_{\mathrm{ef}}=0.04$ will create a zone of saturation more than two feet thick.

Finally, the most important aspect of the model, for the purposes of predicting debris flows, is the capacity of the barrel. This corresponds to the maximum amount of rain water that can be retained in an element of hillslope before the slope becomes unstable and fails. The capacity of a hillslope can be estimated from standard engineering slope stability analyses such as the infinite-slope method of Skempton and DeLory (1957), or more sophisticated computer models such as method-of-slices or finite-elements, but only if the geotechnical properties (cohesion, angle of friction, and saturated bulk density) of the materials, and the hydrologic behavior (e.g., the flow direction) of the hillslope can be determined precisely. If the hillslope materials are heterogeneous, the hydrologic flow patterns are complex, or if vegetation significantly affects the strength of shallow hillslope materials, then the capacities must be estimated by indirect means. Such is the case in the Honolulu District. 


\section{Measurements of Rainfall and Pore Pressures:}

Since March, 1989, we have been measuring rainfall and shallow pore pressures on steep hillslopes at two sites in the Koolau Range, Pauoa Ridge and Kaluanui Ridge (fig. 5). In selecting sites for instrumentation, we attempted to find sites that were similar, in terms of rock and soil types, steepness, elevation, vegetation, and slope geometry, to places where debris flows were triggered during the New Year's Eve storm of 1987-88. The Pauoa Ridge site is located on the ridge between the Nuuanu and Pauoa Valleys, north of downtown Honolulu. The Kaluanui Ridge site is located above the head of Hahaione Valley in the eastern part of the Honolulu District. (A third site, in Halawa Valley, was also installed in 1990, but later abandoned because of pending highway construction.)

The instruments at each site consist of a tipping-bucket rain gage to measure rainfall, and as many as eight shallow piezometers to measure pore pressures at depths ranging from 60 to $180 \mathrm{~cm}$. These instruments are connected to a digital data-logger that automatically reads and records measurements at pre-programmed intervals. The instruments are currently sampled every 15 minutes, 24 hours per day. The data are recorded in a digital format on standard cassette recording tapes. These tapes are collected approximately every two months, and the data is read and analyzed with a computer system.

These measurements were initiated for two purposes: (a) to ascertain whether Campbell's (1975) model is valid for the geologic and climatic conditions in Oahu, and (b) if so, to calibrate the leaky-barrel model for the topographic and hydrologic conditions on Oahu. The principal test for the validity of the Campbell model would be whether positive pore pressures can be detected and correlated with periods of intense rainfall. 
If the existence of positive pore pressures can be demonstrated, then further tests would attempt to calibrate the two leaky-barrel model parameters, drainage coefficient $\left(\mathrm{K}_{\mathrm{d}}\right)$ and effective porosity $\left(\mathrm{N}_{\mathrm{ef}}\right)$, by fitting the model responses to the pore-pressure recordings.

As shown in tables 2 and 3 , a number of positive pore-pressure responses have been recorded at the two principal sites during severe rainstorms over an entire rainfall year (9/90 to 8/91). For the largest storm sequence recorded during this period, March 18-25, 1991, there appears to be good agreement between the response predicted by the leaky-barrel model from observed rainfall intensity and the piezometric response actually observed at both sites (figs. 6, 7). The leaky-barrel parameters that are shown in figures 6 and 7 correspond to drainage halflives of approximately 2 hours for the Pauoa Ridge site and 3.5 hours for the Kaluanui Ridge site.

The leaky-barrel model also predicts that, for most severe rainstorms, a correlation should exist between the peak piezometric response and the maximum rainfall to be accumulated during a period of time comparable to the drainage half-life (Wilson, unpub. data). Plots of peak piezometric response versus peak rainfalls for periods of 3 hours and 6 hours recorded at the Pauoa and Kaluanui sites (figs. 8, 9) indicate that, although a fair amount of scatter is evident, a significant statistical correlation between these two parameters does exist (correlation coefficients significant at 5 per cent level).

Although the results of the monitoring of rainfall and pore pressures are still in a preliminary stage of interpretation, they suggest that the first objective of the measurement program was met: positive pore pressures 
were observed during periods of intense rainfall at depths (0-2m) similar to those involved in soil-slip debris flows.

The second objective, calibration of the leaky-barrel model for conditions on Oahu, has not been completely met, however. At both sites, reasonably consistent values for drainage coefficient and effective porosity can be found so that a leaky-barrel model can fit pore-pressure records from a number of storms fairly well. Yet these same values may fail to fit recordings from other storms at the same site. The role of such variables as antecedent rainfall is still not well understood, and further measurements and analysis may be necessary before we can have full confidence in any single set of calibrations.

Moreover, rainfall and pore-pressure measurements suffer from a severe practical limitation: we can instrument only very limited areas, a few square meters at most. In order to develop practical rainfall warning thresholds for debris flows, it is necessary to derive numerical values that represent areas of many square kilometers. These are much larger areas than can be instrumented at a reasonable cost.

In order to derive these regional thresholds, we must turn to historical information, as discussed below. However, the instrumental measurements provide valuable guidance in analyzing the historical information: we now know that intense rainfall produces variations in pore pressures in steep hillsides over a time-scale of a few hours, so that regional thresholds should be defined in terms of peak rainfall amounts accumulated over similar periods of time. 


\section{Historical Data on Rainfall and Debris Flows:}

In addition to the theoretical and instrumental studies, we collected an extensive set of historical data on rainfall and the occurrence of debris flows during large storms. Hourly rainfall data were collected from a number of rain gages in the Honolulu District for 17 storms, selected to be the largest events during a 33-year period, from $3 / 58$ to $3 / 91$ (table 1 and fig. 5). Historical data on occurrence of debris flows were collected from Oahu Civil Defense Agency (OCDA) logs, newspaper accounts, and various secondary sources, such as post-flood reports and meteorological summaries. This historical database documents the occurrence of debris flows during heavy rainfall over broader areas and a longer time period than our instrumental studies permit. The historical database also allows us to reinforce our theoretical models and short-term instrumental records with the knowledge of actual events, which provides a firmer basis for the development of rainfall warning thresholds.

This historical data (table 1) indicates that debris-flow problems are not uncommon in the Honolulu District. Of the 17 storms for which rainfall data were collected, at least 10 had significant associated debrisflow activity, and several had damage that resulted in at least several debris-flow reports. Because the historical accounts rarely mention debris flows specifically, some interpretation was commonly required to ascertain that debris flows were the actual cause of the damage reported. This extensive collection of historical data is contained in a separate report to the City and County Public Works Department (Torikai and Wilson, unpub. data). 


\section{Derivation of Rainfall Warning Thresholds from Historical Data:}

Subsets of historical rainfall and debris-flow data were selected from two study areas from the Honolulu District for further statistical study (fig. 5). The Nuuanu study area represents the western part of the Honolulu District and extends from Waahila Ridge northwestward to Kalihi Valley. The Kaluanui study area represents the eastern part of the Honolulu district and extends from Palolo Valley eastward to Hawaii Kai. These study areas were selected in an attempt to bring together a group of rain gages representing approximately equivalent rainfall, along with a clustering of debris-flow reports within a reasonable proximity to the selected rain gages. Separate study areas in the eastern and western halves of the Honolulu District were selected to test the hypothesis that sufficient differences in rainfall and vegetation exist between the two areas to possibly affect the rainfall thresholds for debris flows.

Within the Nuuanu area, good historical data on hourly rainfall is available from rain gages in the Honolulu Watershed operated by the Board of Water Supply (BWS). Four BWS rain gages, shown in figure 5, were selected for analysis: Manoa Tunnel \#2 (716), Pauoa Flats (784), Nuuanu Reservoir \# 4 (783), and Kalihi Reservoir site (777). Rainfall data from these four gages were averaged for the statistical analysis of the Nuuanu study area (table 4). Figure 10 shows graphs of the number of debris flows reported in the historical accounts from within the Nuuanu area plotted against average peak rainfall for 1-hour, 3-hour, and 6-hour periods.

While considerable scatter appears among the data points plotted for these storms (Figs. 10A-C), a definite lower bound exists for each of the plots. This lower bound is defined largely by the storms of $2 / 5 / 76$, 
$12 / 31 / 87,11 / 10 / 65$, and $3 / 5 / 58$. The storm of $3 / 6 / 63$, which produced no debris-flow reports, lies beneath the lower bound, thereby providing additional constraint. There appears to be a roughly linear correlation between peak rainfall and the number of debris flows reported for these bounding storms.

The lower-bound lines in figure 10 were used to define two empirical rainfall warning thresholds--a "safety" threshold and an "abundant" threshold. These thresholds are composed of the peak cumulative rainfalls for each of three periods--1, 3, and 6 hours. The peak rainfall values for the safety threshold are obtained by extrapolating the lowerbound lines to vertical lines corresponding to zero reported debris flows. The peak rainfall values for the abundant threshold correspond to the intersections between the lower-bound lines and vertical lines corresponding to 10 reported debris flows. The peak rainfall amounts corresponding to these two thresholds are listed in table $5 \mathrm{~A}$ and shown graphically in figure $10 \mathrm{D}$.

A similar procedure was used in the Kaluanui study area. Peak rainfall for 1-, 3-, and 6-hour periods was plotted against the total number of reported debris flows within the Kaluanui study area, from the historical data (table 6, fig. 11). Peak rainfall in these plots represents the average of three rain gages: Maunawili (787.1), Waimanolo Nonokio (795.2), and Palolo Valley (718). Whereas the Palolo rain gage has been operated by BWS for many years, Maunawili and Waimanolo Nonokio are NWS rain gages and began recording hourly rainfall only in 1969. Because only those storms subsequent to the beginning of hourly operation of the Maunawili and Waimanolo rain gages can be used in the statistical analysis, the historical time base for the Kaluanui study area is 
significantly briefer than that for the Nuuanu study area, which dates to 1958.

The lower bound threshold for the Kaluanui area is not as well defined as that for the Nuuanu area. Nevertheless, we can constrain lower bound threshold rainfall values using the storms of $2 / 1 / 69,1 / 8 / 80$, $1 / 20 / 82,5 / 6 / 81$, and $11 / 10 / 65$. The New Year's Eve storm (12/31/87) is the largest storm, and it appears to lie well above the lower bound threshold for all three measures of peak rainfall. The peak-rainfall values corresponding to the safety and abundant thresholds are defined in the same way as those for the Nuuanu study area. They are listed in table 5B and plotted in figure 11D.

Comparison of the rainfall thresholds for the Kaluanui study area (fig. 11D) with the thresholds for the Nuuanu study area (fig. 10D) reveals differences, particularly in the safety thresholds. The rainfall values for the abundant threshold for Kaluanui are only about 12 per cent larger than those for Nuuanu; this difference is of questionable significance in light of the uncertainties in the two data sets. The safety threshold values for Kaluanui, on the other hand, are two to three times larger than those for Nuuanu.

Several factors may partially explain these differences. One factor is that the peak rainfalls recorded by the Maunawili rain gage (787.1) are higher than those for the other two rain gages in most of the storms of the data set. This factor alone may account for the differences in rainfall values between the abundant thresholds for the two study areas. Another factor is that the smallest bounding storms are different for the two study areas: the storm of $2 / 5 / 76$ for Nuuanu, and the storm of $1 / 20 / 82$ for Kaluanui, with the latter storm having significantly higher 
peak rainfalls. Also, only one storm in each study area had more than the 10 debris-flow reports defined as the abundant threshold: 3/5/58, with 12 reports in the Nuuanu study area (table 4), and 12/31/87, with 17 reports in the Kaluanui study area (table 6). These differences in the smallest and largest storms would have a strong effect on the safety threshold values, which are closely tied to the weakest storm that triggers any reported debris flows, but a somewhat weaker effect on the abundant threshold values, which reflect influences from several storms.

Over and above these statistical factors, however, the differences in thresholds may reflect an actual difference in the conditions that result in debris flows within the two study areas. In the eastern part of the District, the slope failures that form debris flows are typically deeper and occur on gentler slopes than is generally the case in the western part (Ellen, unpub. data). Both factors would increase the hillslope's capacity to retain rainfall and, therefore, would favor higher threshold values in the eastern area.

In light of the differences in thresholds between the Nuuanu and Kaluanui study areas, it is difficult to estimate rainfall warning thresholds that would be appropriate for those portions of the Honolulu District that lie outside of the two study areas. The abundant thresholds developed for the two study areas are similar enough that they might be used, with some confidence, anywhere in the upper reaches of the Koolau Range in the Honolulu District (above 400 feet elevation) by using the Nuuanu values (fig. 10D) to the west of Palolo Valley and the Kaluanui values (fig. 11D) for Palolo Valley and eastward. The differences in the safety thresholds are much greater, but the Nuuanu safety thresholds should be adequately conservative for all areas within the District, outside of the 
Kaluanui study area (fig. 5). Upland areas associated with post-Koolau volcanism, such as Diamond Head, Punchbowl, Tantalus, and the Koko Head complex, were not studied in this investigation, and their rainfall thresholds for debris-flow activity remain unknown.

\section{Application of Rainfall Warning Thresholds for Debris Flows:}

The thresholds derived above still contain a degree of uncertainty about the relationship between peak rainfall amounts and the number of debris flows initiated by the storm. However, they clearly denote the boundary between rainfall amounts that trigger debris flows versus those that do not, and thus they should be adequate for a practical, real-time, debris-flow warning system for the Honolulu District. Use of the thresholds would be similar to the landslide warning system for the San Francisco Bay region. There, the "safety" threshold is used to separate out storms that have a very small chance of triggering debris flows from storms that have a potential for creating hazardous debris flows. The "abundant" threshold is used to define storms that have a very high probability of not only triggering debris flows, but triggering them in sufficient numbers to be a danger to life and property. These storms, therefore, may warrant immediate warning and mitigative action.

Storms that are forecast to fall between the two thresholds are selected for careful observation when the storm actually arrives. Rainfall intensities for these in-between storms are monitored closely in real-time using telemetering rain gages. If rainfall intensity increases beyond that forecast, then warnings are issued. If, conversely, the rainfall falls short of that forecast, then warnings would not be broadcast and emergency agencies would return to normal functioning. 
Both thresholds are conservative, especially the safety threshold. The plots on which the thresholds are based show many storms that lie well above the lower bound thresholds; these are storms in which the rainfall should have been sufficient to trigger more reports of debris flows but, for one reason or another, did not. Some of these discrepancies may reflect unusually dry antecedent conditions. Others may reflect the fact that most debris flows have been triggered in remote areas high in the Koolau range (Peterson and others, unpub. data) and have had little direct effect on developed areas. A number of such debris flows may have been triggered by these storms, but failed to be reported. As development proceeds toward these upland areas and lives and property become more exposed to hazards from debris flows, a greater proportion of debris flows may be reported in the future. Until these discrepancies in the historical storms are better understood, practical operation of a warning system may require the use of conservative thresholds.

Almost certainly, there will be false alarms from the use of such conservative thresholds. False alarms, however, may be preferable to lack of warning for storms that create debris flows. The mitigative steps generally taken for debris-flow hazards, such as temporary evacuations of susceptible neighborhoods and mobilization of emergency crews, are inexpensive compared to the damage and loss of life that can result from lack of warning. For example, local agencies and the general public in the San Francisco Bay area were caught by surprise by the catastrophic storm of January 1982, when debris flows and other fast-moving landslides killed 25 people and caused at least $\$ 66$ million in damage. This disaster led to the establishment of the Landslide Warning System for the San Francisco Bay region. 


\section{Further Steps in the Development of a Warning System:}

The development of rainfall warning thresholds for debris flows is only one step in creating a debris-flow warning system in the Honolulu District. The steps that could be taken by the responsible local, state, and federal agencies to develop an operational debris-flow warning system might include: (1) coordination of available resources for reliable forecasting of severe rainstorms; (2) installation of remote, telemetering rain gages in upland areas, in order to increase the ability to observe rainfall under real-time conditions; and, (3) development of an administrative system for collecting and analyzing the rainfall data, making the decision to issue a warning, and communicating the warning to the public. Finally, responsible local agencies may wish to plan the steps that could be taken to mitigate debris-flow hazards should a warning system be created, including: (a) training police and fire units to respond to debris flow hazards, (b) organizing emergency crews to clean out drainages and clear roadways, and (c) planning evacuation procedures for especially susceptible neighborhoods. 


\section{References Cited:}

Browning, K. A., and Collier, C. G., 1989, Nowcasting of precipitation systems: Reviews of Geophysics, v. 27, p. 345-370.

Campbell, R. H., 1975, Soil slips, debris flows, and rainstorms in the Santa Monica Mountains and vicinity, Southern California: U. S. Geological Survey Professional Paper 851, 51 p.

Dracup, J. A., Cheng, E. D. H., Nigg, J. M., and Schroeder, T. A., 1991, The New Year's Eve flood on Oahu, Hawaii, December 31, 1987 - January 1, 1988: National Research Council, Natural Disaster Studies, v. 1, 72 p.

Ellen, S. D., and Fleming, R. W., 1987, Mobilization of debris flows from soil slips, San Francisco Bay region, California: in Costa, J. E., and Wieczorek, G. F., eds., Debris Flows/Avalanches: process, recognition, and mitigation: Reviews in Engineering Geology, v. VII, Geological Society of America, p. 31-40.

Ellen, S. D., Iverson, R. M., and Pierson, T. C., 1991, Map showing the distribution of debris flows during the New Year's Eve storm of 19871988 in southeastern Oahu, Hawaii: U. S. Geological Survey Open-File Report 91-129, scale 1:20,000.

Ellen, S. D., and Wieczorek, G. F., 1988, Landslides, floods, and marine effects of the storm of January 3-5, 1982, in the San Francisco Bay region, California: U. S. Geological Survey Professional Paper 1434, 310 p.

Giambelluca, T. W., Nullet, M. A., and Schroeder, T. A, 1986, Rainfall Atlas of Hawaii: State of Hawaii, Department of Land and Natural Resources, Report R76, 55 p.

Interagency Flood Hazard Mitigation Team, 1988, disaster declaration FEMA-808-DR-HI: Federal Emergency Management Agency, 34 p.

Keefer, D. K., Wilson, R. C., Mark, R. K., Brabb, E. E., Brown, W. M., Ellen, S. D., Harp, E. L., Wieczorek, G. F., Alger, C. S., and Zatkin, R. S., 1987, Realtime landslide warning during heavy rainfall: Science, v. 238, p. 921925 . 
Scott, G. A. J., 1969, Relationships between vegetation and soil avalanching in the high rainfall areas of Oahu, Hawaii: University of Hawaii, M. A. Thesis, $98 \mathrm{p}$.

Scott, G. A. J., and Street, J. M., 1976, The role of chemical weathering in the formation of Hawaiian amphitheatre-headed valleys: Zeitschrift fur Geomorphologie, v. 20, no. 2, p. 171-189.

Skempton, A. W., and DeLory, F. A., 1957, Stability of natural slopes in London Clay: International Conference on Soil Mechanics and Foundation Engineering, 4th, London, 1957, Proceedings, v. 2, p. 139152.

State of Hawaii, 1988, Post flood report, New Year's Eve storm, December 31, 1987-January 1, 1988, windward and leeward east Oahu: State of Hawaii, Department of Land and Natural Resources, Circular C119, 55 p.

Terzaghi, K., 1950, Mechanism of landslides: in Paige, S., Ed., Application of geology to engineering practice, Berkey Volume: Geological Society of America, New York, p. 83-123.

Wentworth, C. K., 1943, Soil avalanches on Oahu, Hawaii: Geological Society of America Bulletin, v. 54, pp. 53-64.

Wilson, R. C., 1989, Rainstorms, pore pressures, and debris flows: a theoretical framework: in Sadler, P. M., and Morton, D. M., eds., Landslides in a semi-arid environment: Publications of the Inland Geological Society, v. 2, p. 101-117. 
Table 1. Storms selected for collection of data on rainfall and debris-flow occurrence, 1958-1991.

Beginning date of storm

$3 / 5 / 58$

$3 / 6 / 63$

$5 / 14 / 63$

$2 / 3 / 65$

$11 / 10 / 65$

$12 / 17 / 67$

$1 / 31 / 69$

$2 / 14 / 69$

$2 / 5 / 76$

$5 / 11 / 77$

$10 / 30 / 78$

$1 / 7 / 80$

$5 / 6 / 81$

$1 / 20 / 82$

$2 / 12 / 85$

$12 / 30 / 87$

$3 / 17 / 91$
Total number of debris flow complaints*
33

0

3

2

21

16

1

0

2

1

2

6

3

7

2

49

34

*Compiled from Oahu Civil Defense Agency logs, newspaper accounts, and secondary sources such as post-flood reports and meteorological summaries. This column includes debris-flow reports from areas outside of the two study areas selected for derivation of rainfall warning thresholds, and so this total may exceed the sum of the numbers of debrisflow reports in Tables 4 and 6 . 
Table 2. Peak rainfall and peak response of piezometer \#7, Pauoa Ridge station, 9/90-9/91.

$\begin{array}{rcccc}\begin{array}{c}\text { Date of } \\ \text { storm event }\end{array} & \begin{array}{c}\text { Peak hourly } \\ \text { rainfall } \\ (\mathrm{cm})\end{array} & \begin{array}{c}\text { Peak 3- } \\ \text { hour } \\ \text { rainfall } \\ (\mathrm{cm})\end{array} & \begin{array}{c}\text { Peak 6- } \\ \text { hour } \\ \text { rainfall } \\ (\mathrm{cm})\end{array} & \begin{array}{c}\text { Peak } \\ \text { response of } \\ \text { piezo. \#7 } \\ (\mathrm{cm})\end{array} \\ 9 / 30 / 90 & 0.9 & 1.6 & 2.6 & \\ 11 / 16 / 90 & 1.8 & 3.7 & 6.9 & 20.77 \\ 12 / 9 / 90 & 0.7 & 1.7 & 3.2 & 8.92 \\ 12 / 14 / 90 & 0.9 & 1.3 & 1.4 & 6.73 \\ 12 / 18 / 90 & 4.2 & 4.8 & 5.1 & 14.21 \\ 1 / 7 / 90 & 0.6 & 1.3 & 1.8 & 8.46 \\ 2 / 18 / 91 & 2.8 & 3.6 & 3.7 & 4.39 \\ 2 / 20 / 91 & 0.9 & 1.8 & 2.8 & 5.74 \\ 3 / 9 / 91 & 1.0 & 1.9 & 3.7 & 3.55 \\ 3 / 12 / 91 & 0.7 & 1.6 & 1.9 & 5.21 \\ 3 / 19 / 91 & 2.3 & 4.5 & 7.0 & 21.32 \\ 4 / 8 / 91 & 1.7 & 2.2 & 3.4 & 11.79 \\ 4 / 26 / 91 & 1.0 & 2.3 & 2.7 & 10.20 \\ 6 / 3 / 91 & 1.2 & 2.5 & 2.7 & 6.27 \\ 8 / 8 / 91 & 2.0 & 4.7 & 6.1 & 19.78\end{array}$


Table 3. Peak rainfall and peak response of piezometer \#2, Kaluanui Ridge station, 9/90-9/91.

$\begin{array}{ccccc}\begin{array}{c}\text { Date of } \\ \text { storm event }\end{array} & \begin{array}{c}\text { Peak hourly } \\ \text { rainfall } \\ (\mathrm{cm})\end{array} & \begin{array}{c}\text { Peak 3- } \\ \text { hour } \\ \text { rainfall } \\ \text { (cm) }\end{array} & \begin{array}{c}\text { Peak 6- } \\ \text { hour } \\ \text { rainfall } \\ \text { (cm) }\end{array} & \begin{array}{c}\text { Peak } \\ \text { response of } \\ \text { piezo. \#2 } \\ \text { (cm) }\end{array} \\ 9 / 16 / 90 & 1.14 & 1.45 & 1.45 & 10.50 \\ 9 / 30 / 90 & 1.70 & 2.11 & 2.24 & 23.33 \\ 11 / 12 / 90 & 1.40 & 3.23 & 4.29 & 21.30 \\ 11 / 13 / 90 & 2.77 & 4.24 & 4.95 & 41.12 \\ 11 / 16 / 90 & 0.81 & 1.30 & 2.18 & 23.72 \\ 11 / 17 / 90 & 0.81 & 1.75 & 2.59 & 34.23 \\ 11 / 19 / 90 & 0.86 & 1.27 & 1.42 & 12.98 \\ 11 / 22 / 90 & 0.99 & 1.09 & 1.12 & 1.72 \\ 11 / 23 / 90 & 0.48 & 0.66 & 0.71 & 6.99 \\ 12 / 23 / 90 & 0.79 & 0.97 & 1.65 & 20.58 \\ 12 / 25 / 90 & 0.64 & 0.71 & 1.17 & 13.91 \\ 1 / 27 / 91 & 1.57 & 3.07 & 3.20 & 20.85 \\ 2 / 13 / 91 & 1.17 & 2.95 & 3.94 & 11.57 \\ 2 / 18 / 91 & 1.42 & 1.47 & 1.47 & 13.23 \\ 3 / 19 / 91 & 4.11 & 8.79 & 13.69 & 60.68 \\ 3 / 21 / 91 & 1.27 & 2.51 & 2.54 & 54.06 \\ 3 / 23 / 91 & 5.28 & 11.05 & 14.05 & 61.55 \\ 4 / 9 / 91 & 1.07 & 2.69 & 3.71 & 12.92 \\ 5 / 19 / 91 & 1.96 & 2.11 & 2.11 & 0.06\end{array}$


Table 4. Peak rainfall and number of debris flow reports for selected storms, Nuuanu study area.

\begin{tabular}{rcccc}
\multicolumn{1}{c}{$\begin{array}{c}\text { Date of } \\
\text { storm }\end{array}$} & $\begin{array}{c}\text { Peak hourly } \\
\text { rainfall (in) }\end{array}$ & $\begin{array}{c}\text { Peak 3-hour } \\
\text { rainfall (in) }\end{array}$ & $\begin{array}{c}\text { Peak 6-hour } \\
\text { rainfall (in) }\end{array}$ & $\begin{array}{c}\text { Number of } \\
\text { reports }\end{array}$ \\
$3 / 5 / 58$ & 2.00 & 4.267 & 6.40 & 12 \\
$3 / 6 / 63$ & 0.50 & 0.667 & 0.833 & 0 \\
$5 / 14 / 63$ & 2.30 & 4.733 & 6.333 & 3 \\
$2 / 3 / 65$ & 2.60 & 4.05 & 5.45 & 0 \\
$11 / 10 / 65$ & 1.575 & 3.40 & 5.025 & 9 \\
$12 / 17 / 67$ & 2.00 & 4.475 & 7.90 & 2 \\
$1 / 31 / 69$ & 1.033 & 2.00 & 2.73 & 1 \\
$2 / 14 / 69$ & 0.567 & 1.20 & 1.77 & 0 \\
$2 / 5 / 76$ & 0.80 & 1.35 & 2.025 & 2 \\
$5 / 11 / 77$ & 1.933 & 4.80 & 5.70 & 1 \\
$10 / 30 / 78$ & 0.933 & 2.367 & 3.733 & 2 \\
$1 / 7 / 80$ & 2.00 & 2.767 & 3.233 & 0 \\
$5 / 6 / 81$ & 1.733 & 3.40 & 5.50 & 3 \\
$1 / 20 / 82$ & 0.967 & 2.067 & 3.033 & 2 \\
$2 / 12 / 85$ & 1.70 & 2.433 & 2.80 & 6 \\
$12 / 31 / 87$ & 1.175 & 2.70 & 4.03 & 3 \\
$3 / 19 / 91$ & 1.463 & 3.038 & 4.30 &
\end{tabular}

Notes: (1) Peak rainfall values are averages for four rain gages: Manoa Tunnel \#2 (716), Nuuanu Reservoir \#4 (783), Pauoa Flats (784), and Kalihi (777). (2) Number of debris flow reports refers only to locations within the Nuuanu study area. 
Table 5A: Rainfall warning thresholds for debris flows, Nuuanu study area.

$\begin{array}{ccc}\begin{array}{c}\text { Duration of } \\ \text { severe rainfall } \\ \text { (hours) }\end{array} & \begin{array}{c}\text { Cumulative rainfall } \\ \text { for safety threshold } \\ \text { (inches) }\end{array} & \begin{array}{c}\text { Cumulative rainfall } \\ \text { for abundant } \\ \text { threshold } \\ \text { (inches) }\end{array} \\ 1.0 & & \\ 3.0 & 0.60 & 1.56 \\ 6.0 & 0.77 & 3.70 \\ & 1.15 & 5.50\end{array}$

Table 5B: Rainfall warning thresholds for debris flows, Kaluanui study area.

Duration of severe Cumulative rainfall rainfall (hours) for safety threshold (inches)
Cumulative rainfall for abundant threshold (inches)
1.0

3.0

6.0
1.05

2.06

3.50
1.63

4.20

6.30 
Table 6. Peak rainfall and number of debris flow reports for selected storms, Kaluanui study area.

$\begin{array}{ccccc}\begin{array}{c}\text { Date of } \\ \text { storm }\end{array} & \begin{array}{c}\text { Peak hourly } \\ \text { rainfall (in) }\end{array} & \begin{array}{c}\text { Peak 3-hour } \\ \text { rainfall (in) }\end{array} & \begin{array}{c}\text { Peak 6-hour } \\ \text { rainfall (in) }\end{array} & \begin{array}{c}\text { Number of } \\ \text { reports }\end{array}\end{array}$

$\begin{array}{rllll}11 / 10 / 65 & 1.4 & 3.375 & 5.225 & 6 \\ 12 / 17 / 67 & 2.175 & 5.27 & 9.52 & 7 \\ 1 / 31 / 69 & 1.6 & 2.425 & 2.885 & 0 \\ 2 / 14 / 69 & 0.675 & 1.55 & 2.545 & 0 \\ 2 / 5 / 76 & 0.85 & 1.517 & 2.267 & 0 \\ 5 / 11 / 77 & 2.517 & 4.57 & 5.517 & 0 \\ 10 / 30 / 78 & 1.333 & 2.767 & 4.267 & 0 \\ 1 / 7 / 80 & 1.333 & 2.567 & 3.633 & 0 \\ 5 / 6 / 81 & 1.267 & 2.667 & 4.833 & 3 \\ 1 / 20 / 82 & 1.133 & 2.333 & 3.867 & 1 \\ 2 / 12 / 85 & 3.967 & 5.267 & 5.367 & 0 \\ 12 / 31 / 87 & 3.267 & 7.667 & 12.533 & 17 \\ 3 / 19 / 91 & 1.875 & 3.85 & 6.275 & 7\end{array}$

Notes: (1) Peak rainfall values are averages for three rain gages: Palolo (718), Maunawili (787.1) and Waimanolo (795.2). (2) Number of debris flow reports refers only to locations within the Kaluanui study area. 


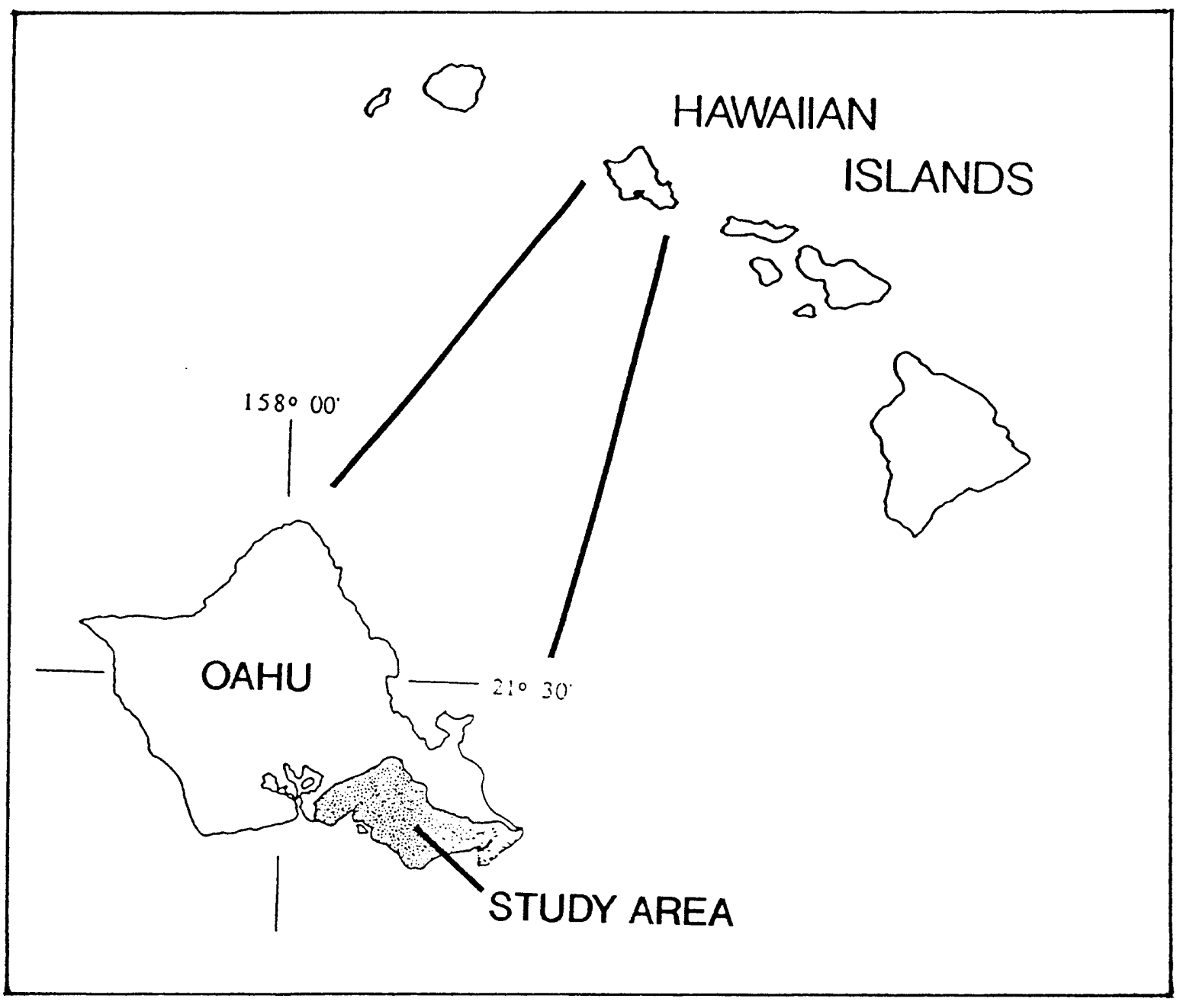

Figure 1. Index map of the Honolulu District, Oahu, Hawaii.

33 


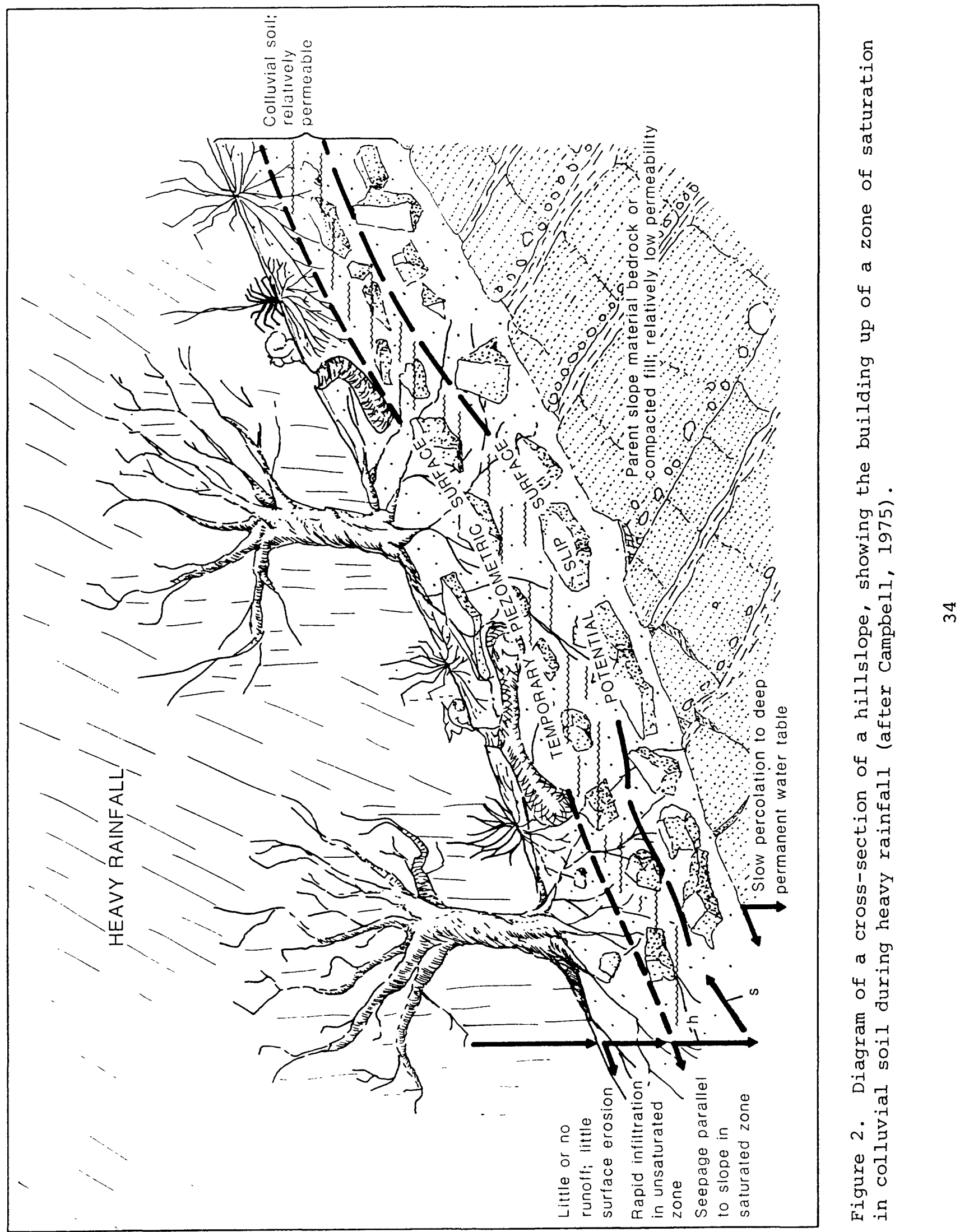




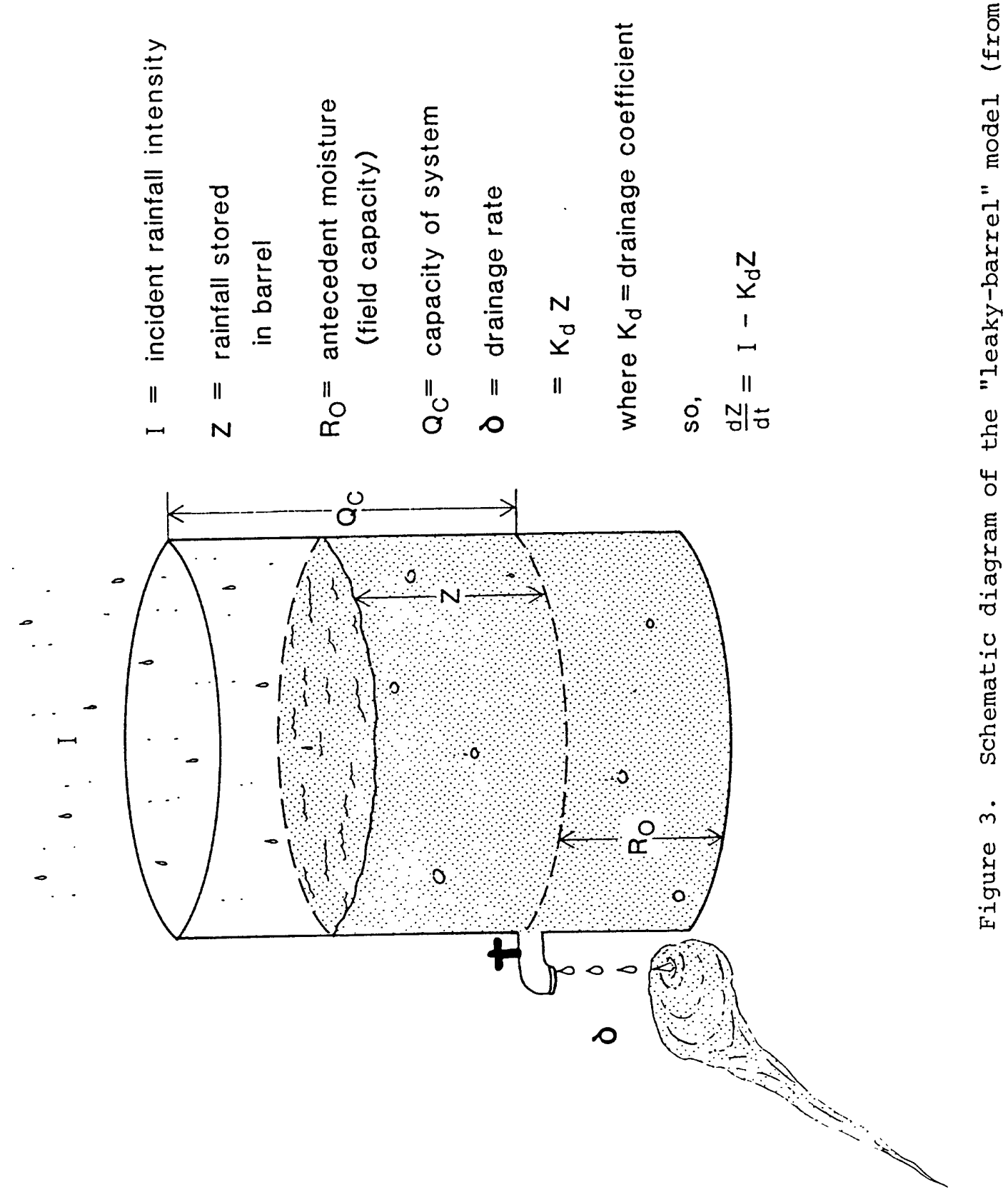

Oे
0
0
0
-1
ci
0
0
$-1-1$
3 
Response of Leaky Barrel Model to Rainfall Pulse of Constant Intensity

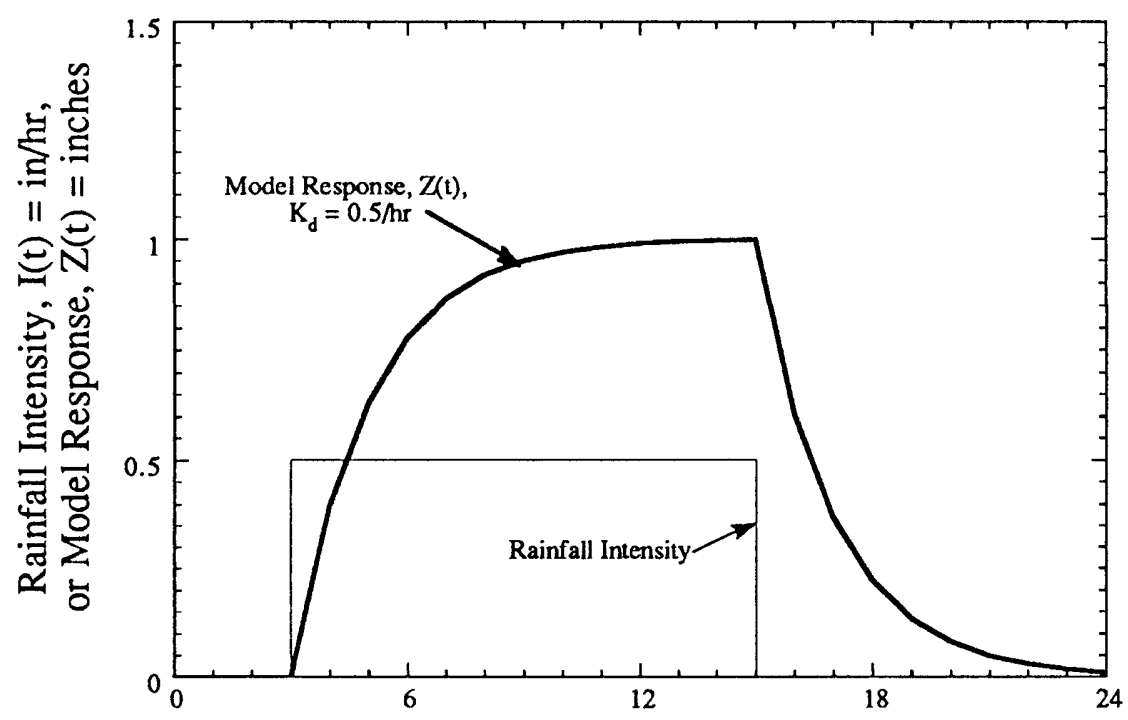

A.

Time (hours)

Response of Leaky Barrel Model to Idealized Rainfall Burst

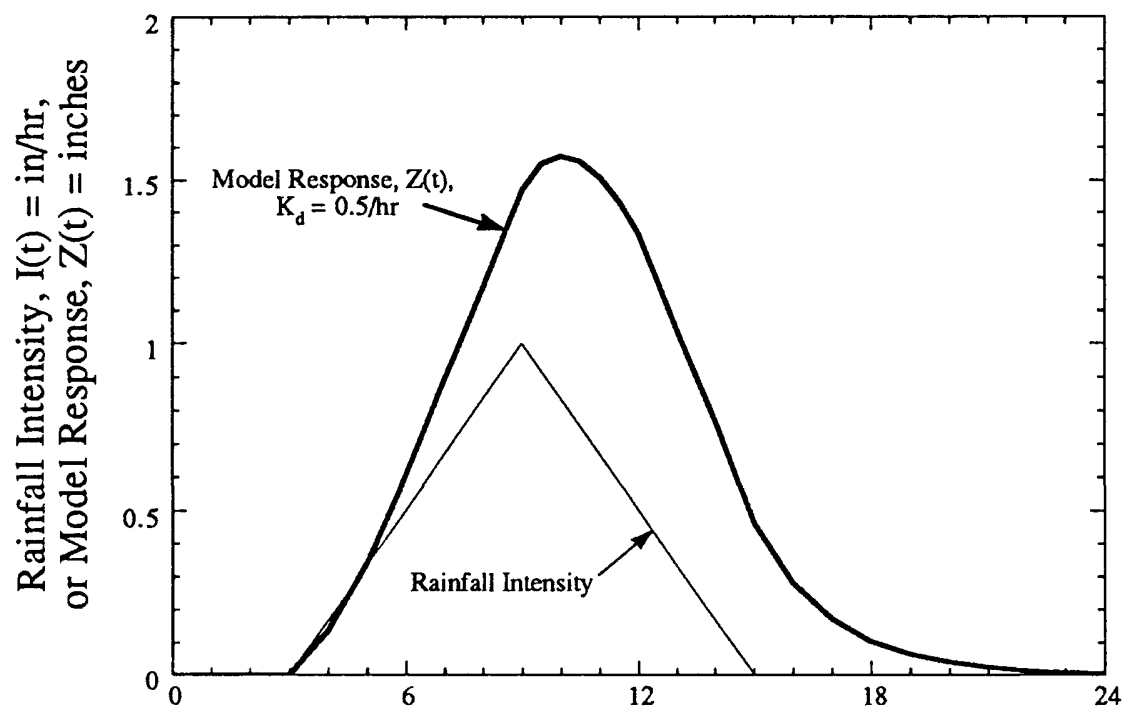

B.

Time (hours)

Figure 4. Graphs showing response of the leaky barrel model $(\mathrm{Kd}=0.5 / \mathrm{hr})$ to two idealized rainfall patterns: (A) rainfall at constant intensity ( $\mathrm{Io}=0.5 \mathrm{in} / \mathrm{hr}$ ) for a duration of 12 hours; (B) rainfall linearly increasing for 6 hours to a peak intensity of $1.0 \mathrm{in} / \mathrm{hr}$, then linearly decreasing for 6 hours back to zero. Total rainfall is 6 inches for both cases. 


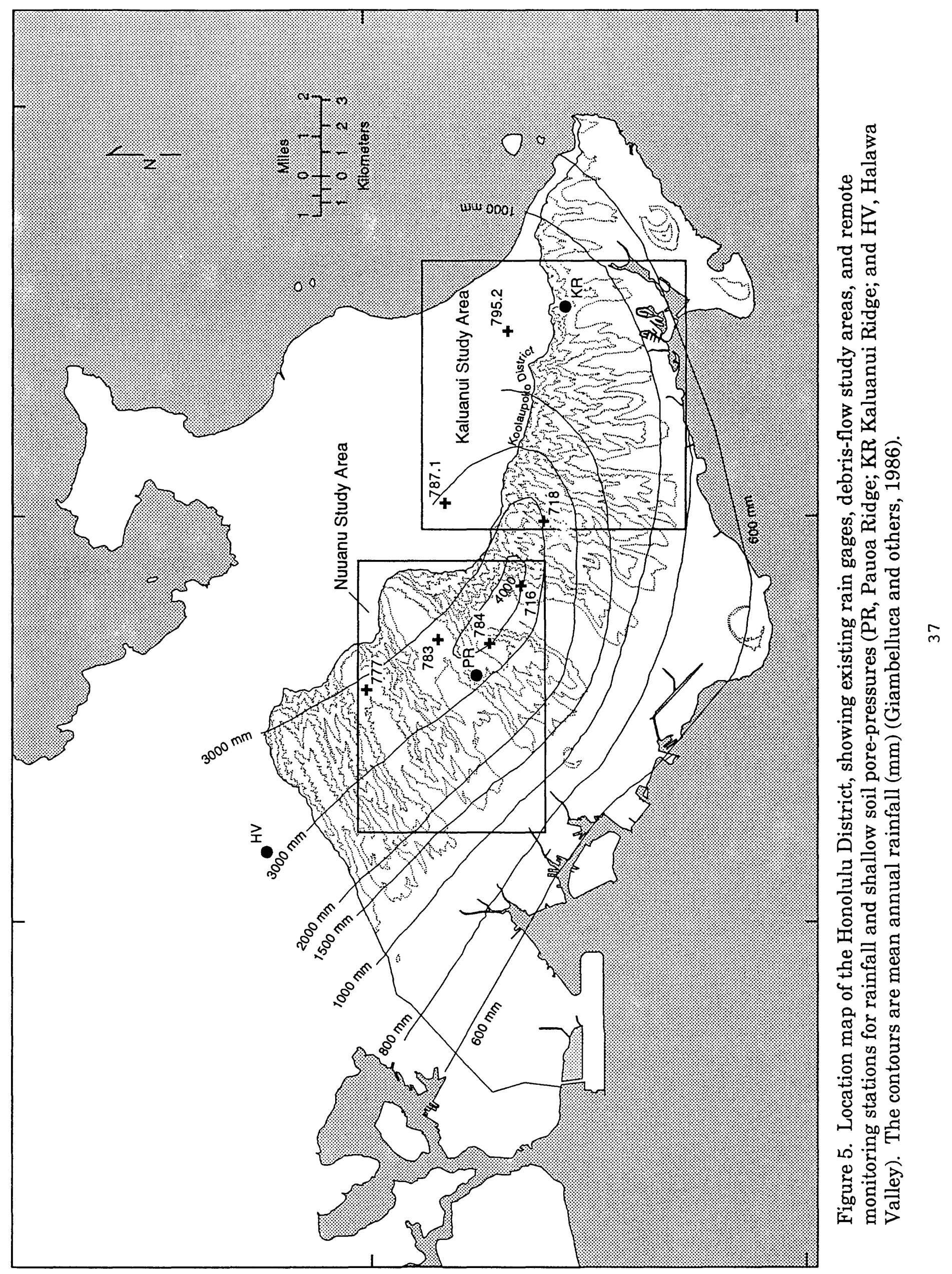




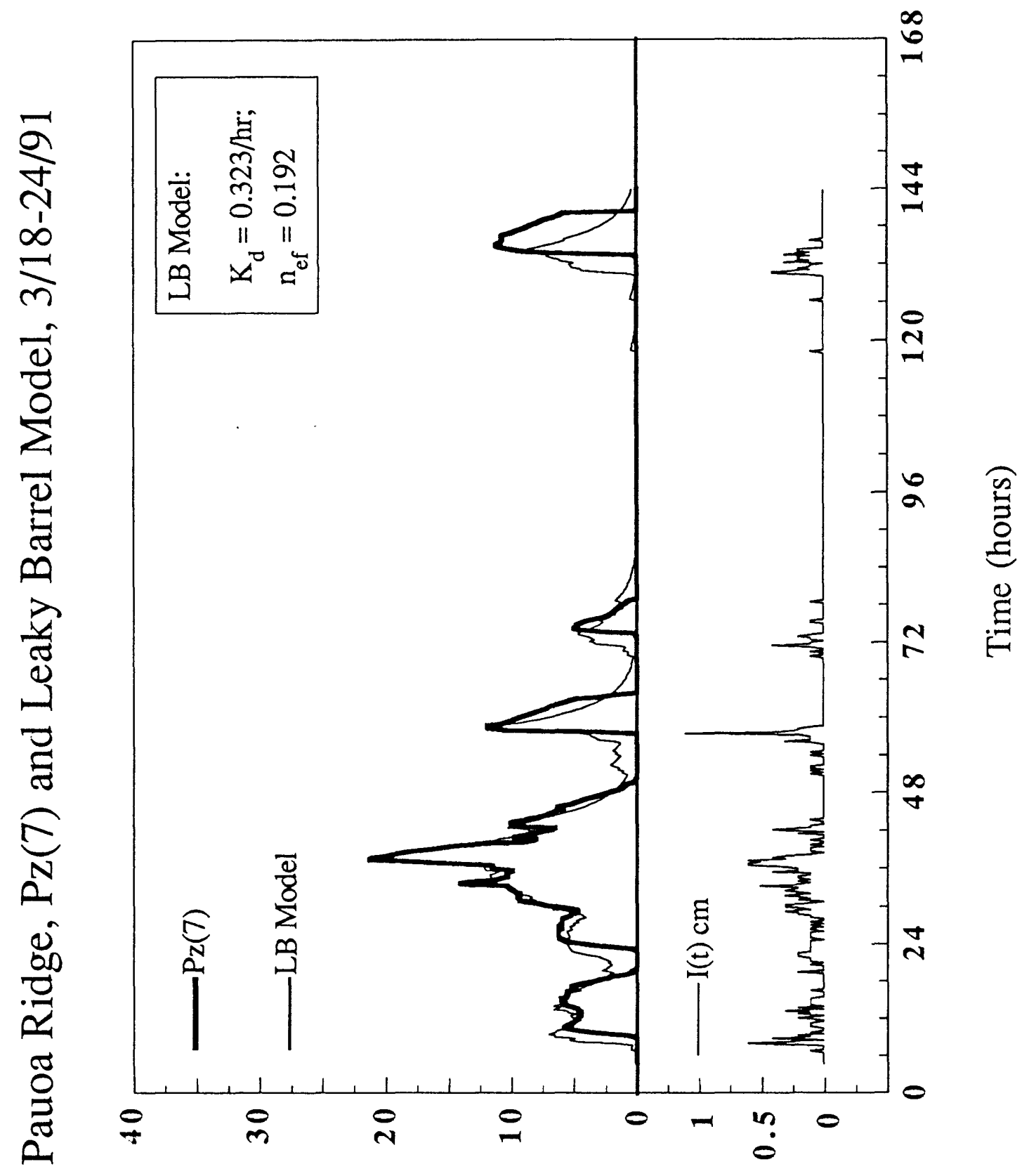

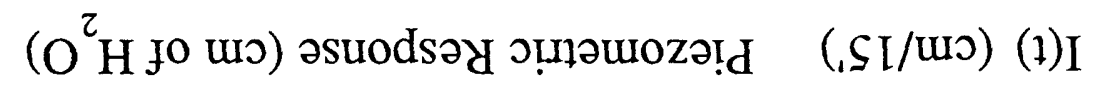

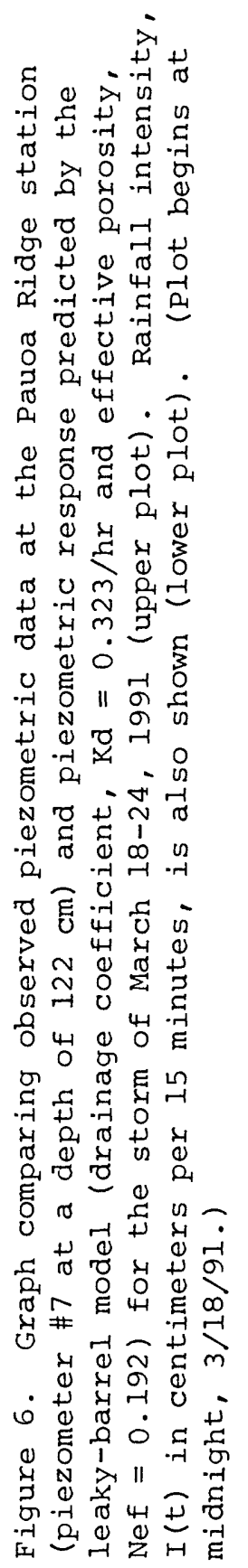




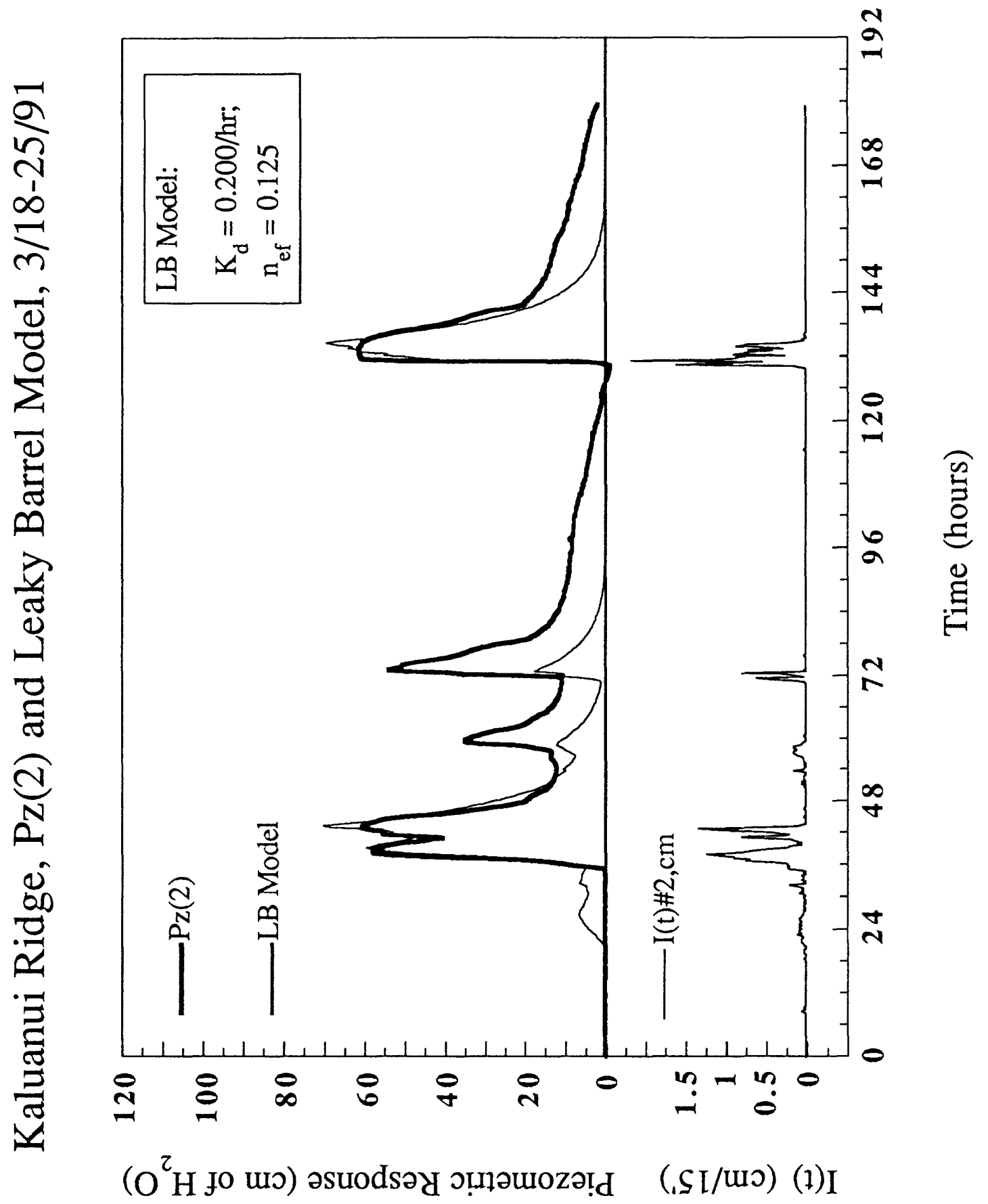

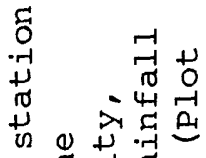
o 然合 तु 0 苛 उ. वृ

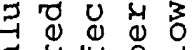

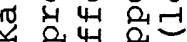
(1) 0 ह

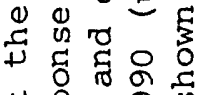
+ ०ू क \&

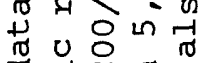
ช

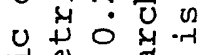
嵌 +) 氙议 N 2 约 d d ๘ ช 0 मे छु फ्स प्र के

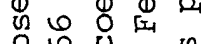
足 0 出

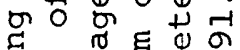
- $ᄃ$ \& $E$ ह 푸 임 प्र है $0 \mathrm{U}$

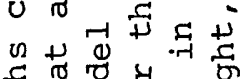

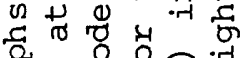

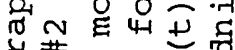
Uु \# ब) प्र $\therefore+\frac{1}{0}$ त्र (1) है 0 व 0 . भ N $2 \|$

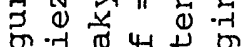

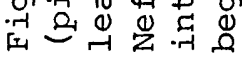


Peak Piezometer Response vs. Peak 3-Hour Rainfall, Pauoa Ridge Station, '90-'91 Season

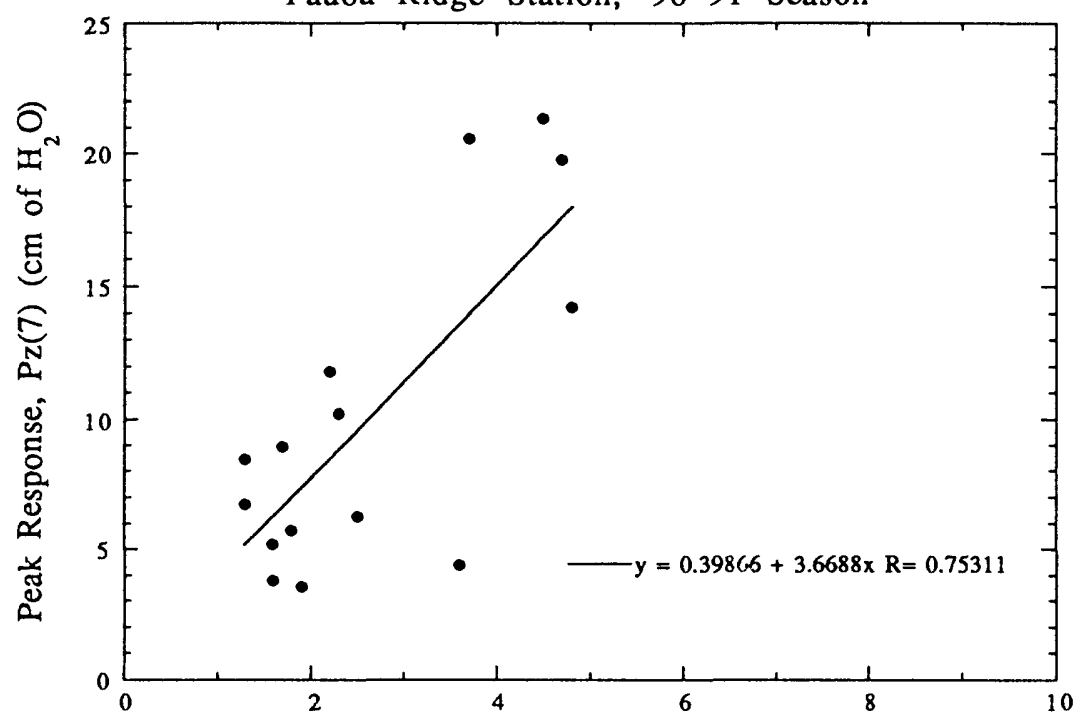

A.

Peak 3-Hour Rainfall (cm)

Peak Piezometer Response vs. Peak 6-Hour Rainfall, Pauoa Ridge Station, '90-'91 Season

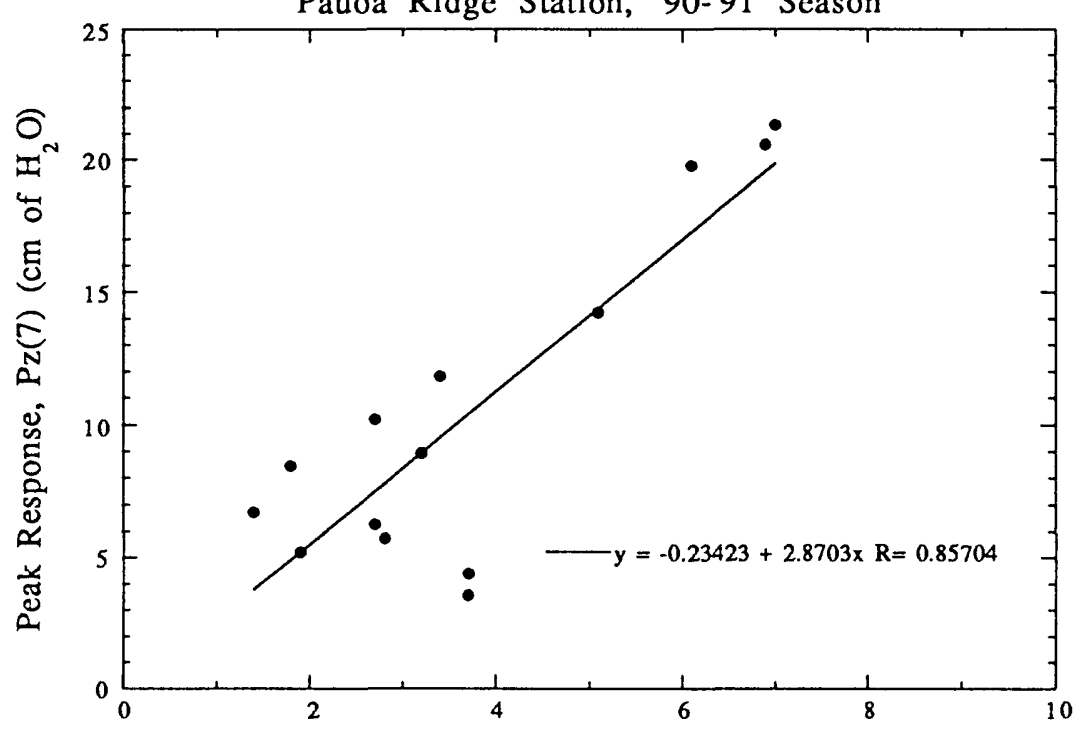

B.

Peak 6-Hour Rainfall (cm)

Figure 8. Graphs plotting peak piezometric response (piezometer \#7) at the Pauoa Ridge monitoring station, versus (A) peak 3-hour rainfall and (B) peak 6-hour rainfall. 
Peak Piezometer Response vs. Peak 3-Hour Rainfall, Kaluanui Ridge Station, '90-'91 Season

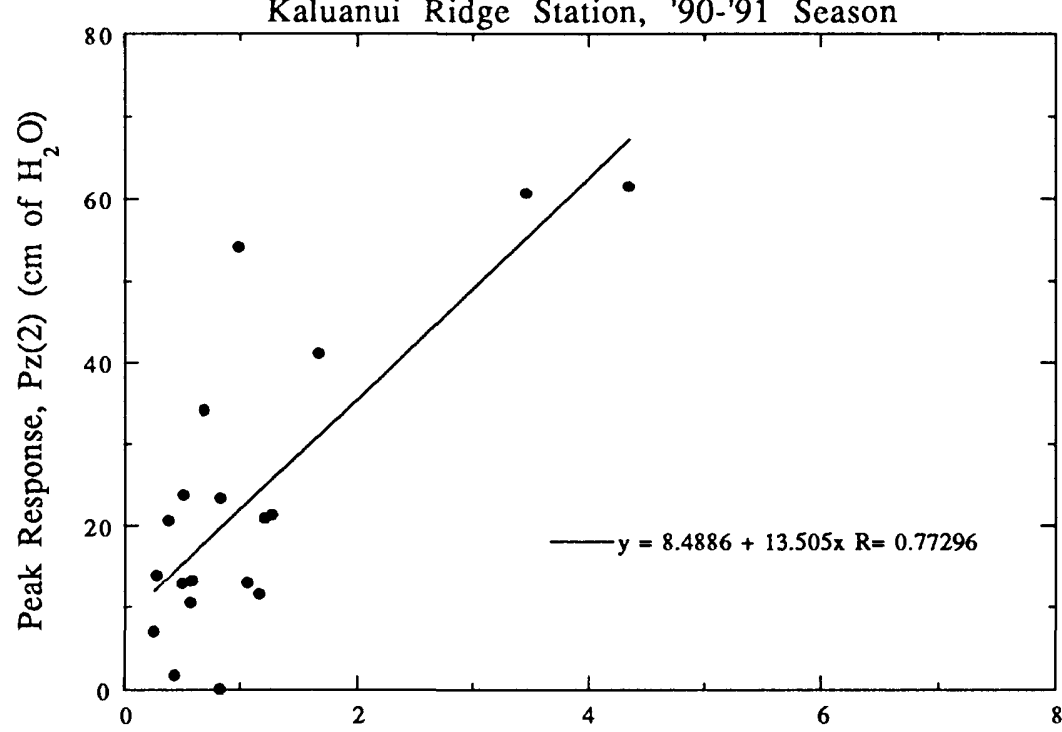

A.

Peak 3-Hour Rainfall (inches)

Peak Piezometer Response vs. Peak 6-Hour Rainfall, Kaluanui Ridge Station, '90-'91 Season

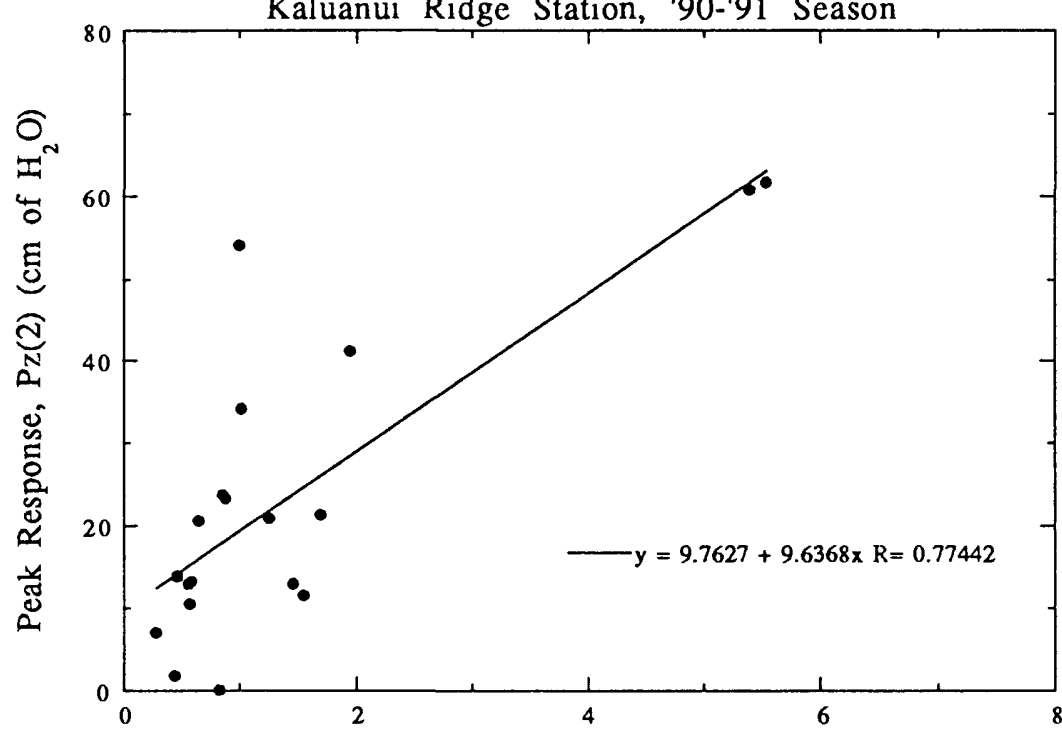

B.

Peak 6-Hour Rainfall (inches)

Figure 9. Graphs plotting peak piezometric response (piezometer \#2) at the Kaluanui Ridge monitoring station, versus (A) peak 3-hour rainfall and (B) peak 6-hour rainfall. 
Peak Hourly Rainfall vs. Number of Debris-Flow Reports in Nuuanu Study Area

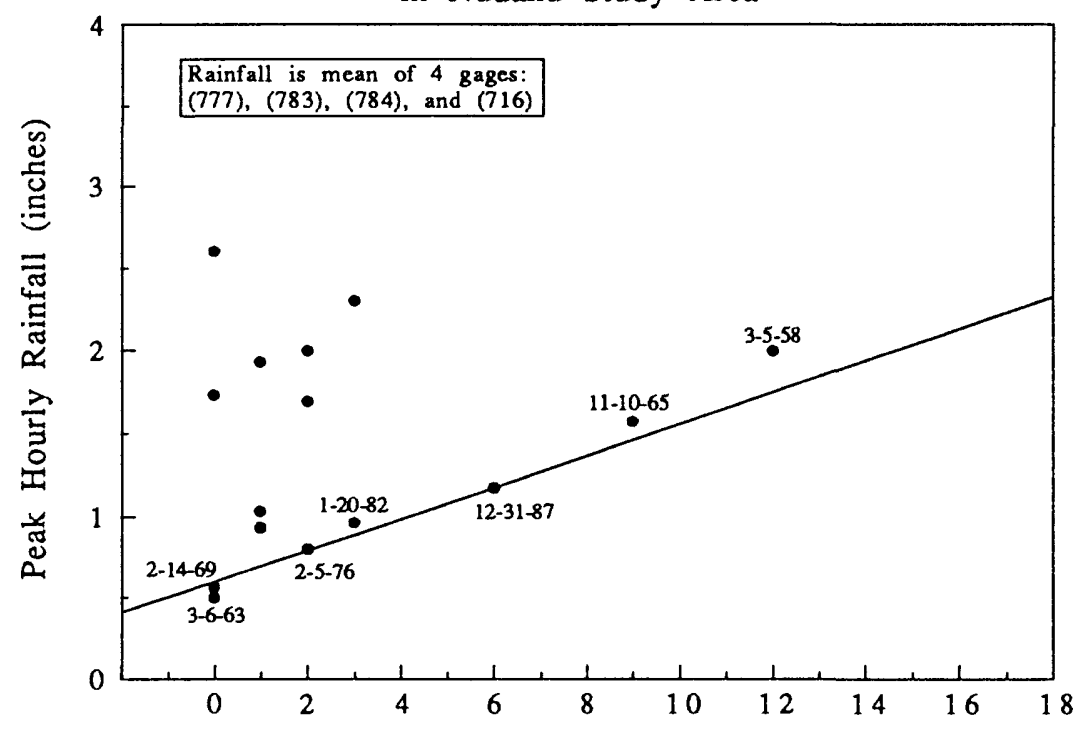

A.

Number of Reported Debris Flows

Figure 10A. Peak hourly rainfall versus the number of debris flow reports for historical storms in the Nuuanu study area (see table 4 and figure 5 ).

Peak 3-Hour Rainfall vs. Number of Debris-Flow Reports in Nuuanu Study Area

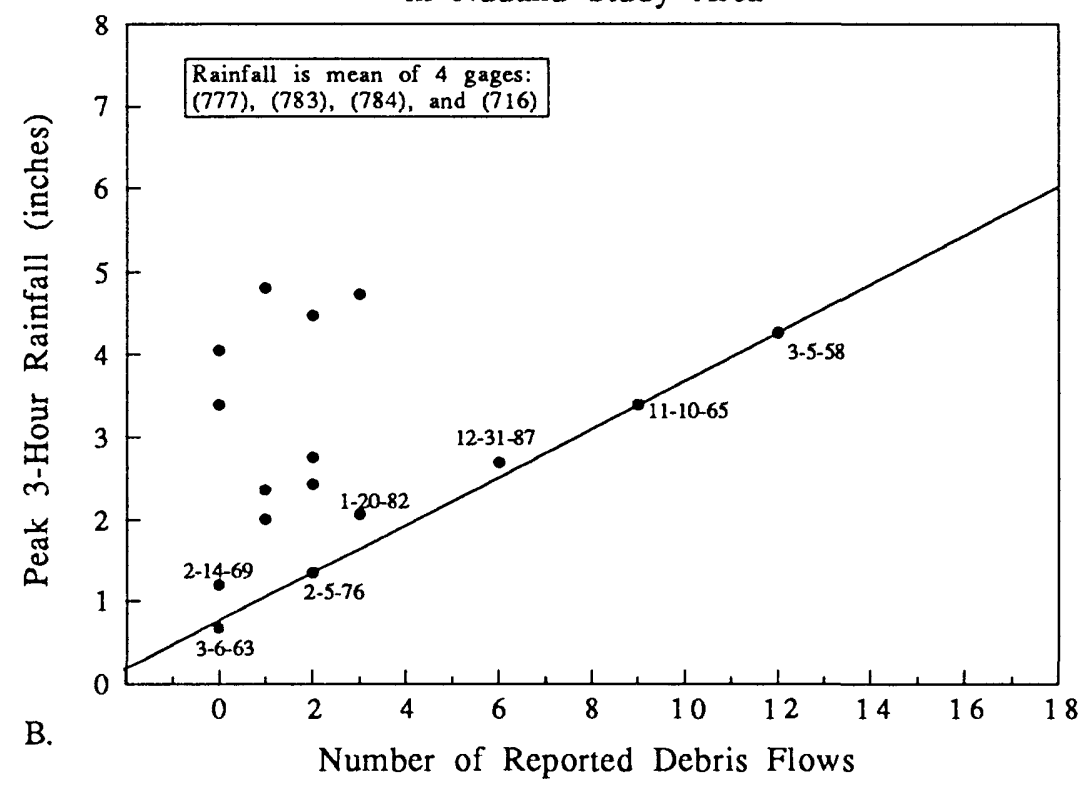

Figure 10B. Peak three-hour rainfall versus the number of debris flow reports for historical storms in the Nuuanu study area (see table 4 and figure 5). 
Peak 6-Hour Rainfall vs. Number of Debris-Flow Reports in Nuuanu Study Area

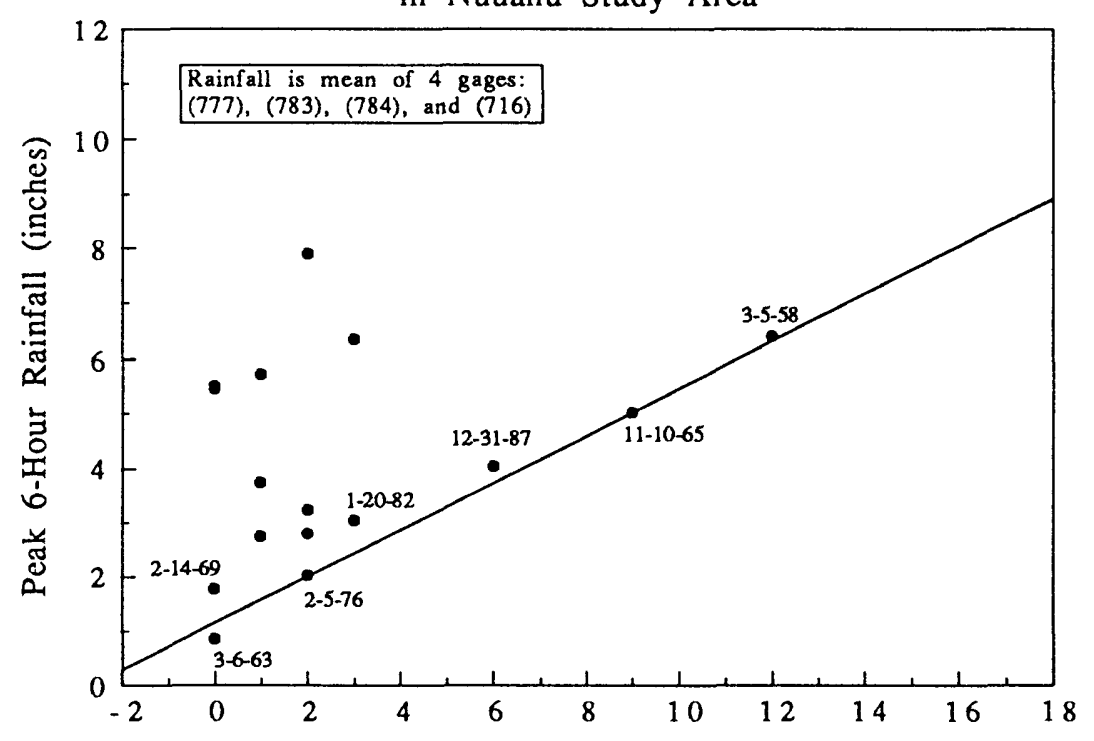

C.

Number of Reported Debris Flows

Figure 10C. Peak six-hour rainfall versus the number of debris flow reports for historical storms in the Nuuanu study area (see table 4 and figure 5).

Rainfall/Debris-Flow Thresholds for Nuuanu Study Area

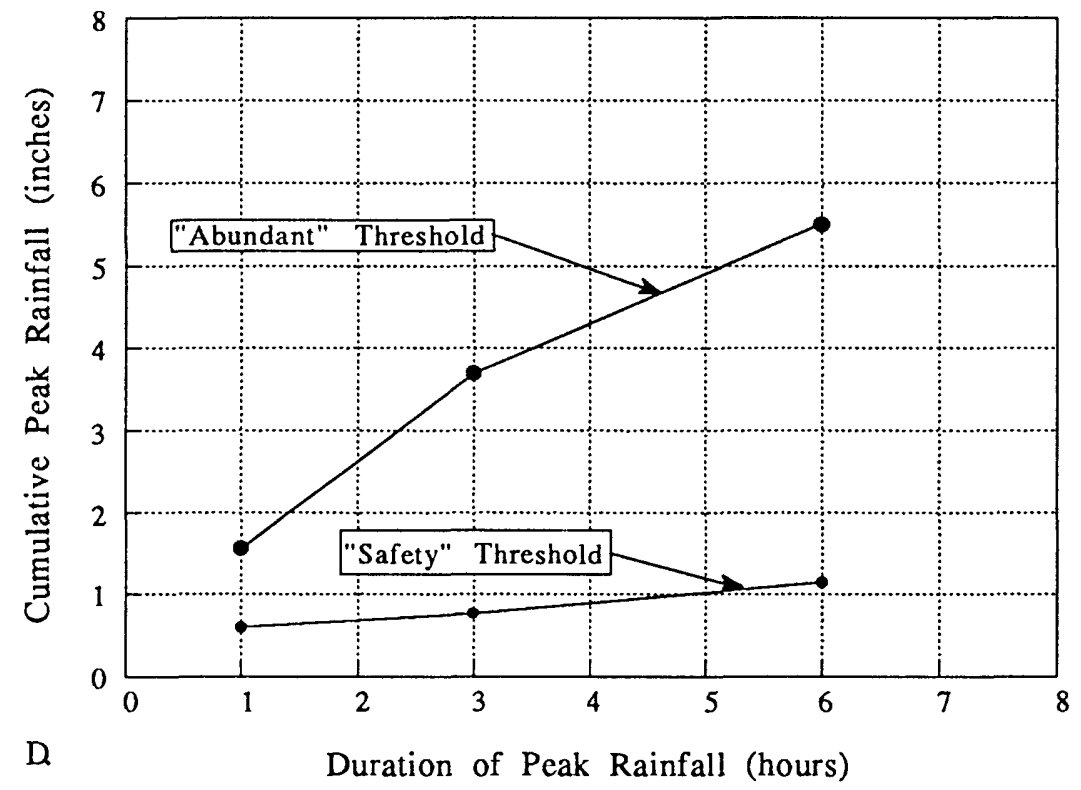

Figure 10D. Rainfall warning thresholds for the initiation of debris flows in the Nuuanu study area, derived from the historical data (table 4) plotted above. (See text for explanation of derivation and use of "Abundant" and "Safety" thresholds.) 
Peak Hourly Rainfall vs. Number of Debris-Flow Reports, Kaluanui Study Area

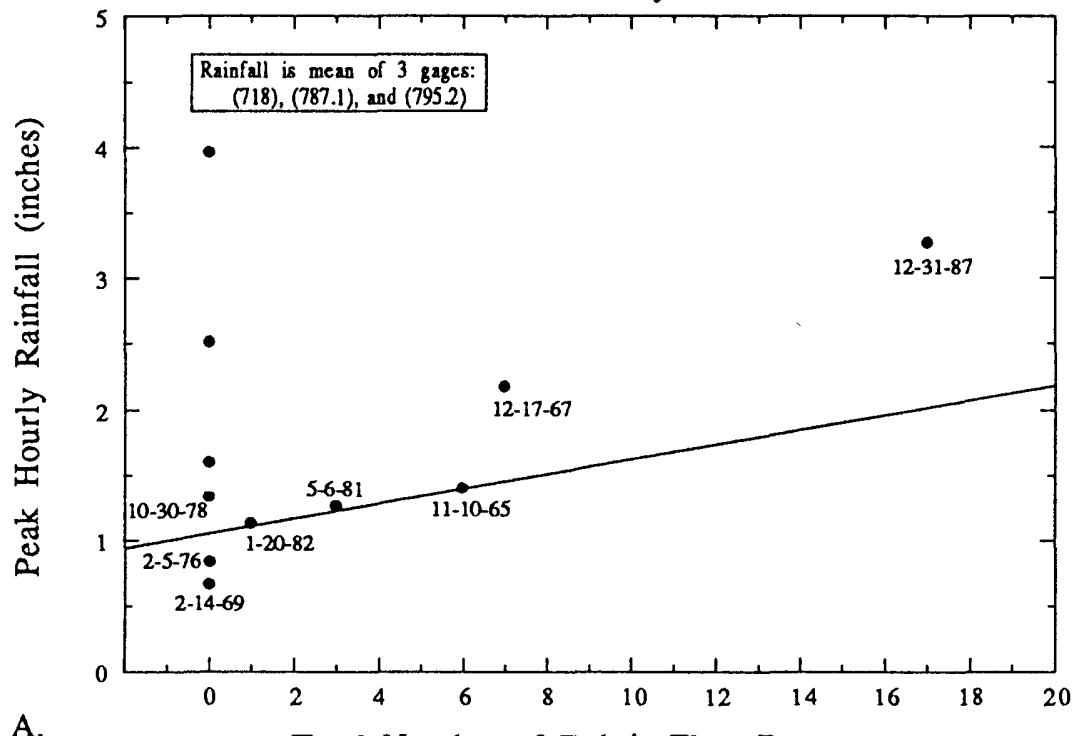

Total Number of Debris Flow Reports

Figure 1lA. Peak hourly rainfall versus the number of debris flow reports for historical storms in the Kaluanui study area (see table 6 and figure 5).

Peak 3-Hour Rainfall vs. Number of Debris-Flow Reports, Kaluanui Study Area

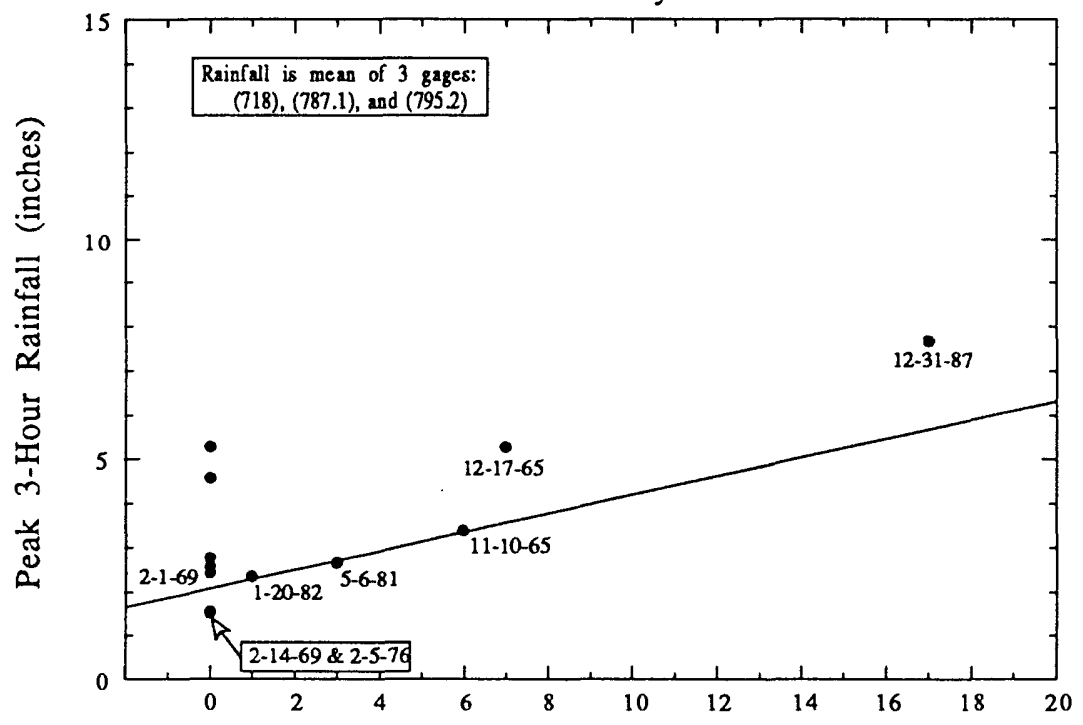

B.

Total Number of Debris Flow Reports

Figure 1lB. Peak three hour rainfall versus the number of debris flows from historical storms in the Kaluanui study area (see table 6 and figure 5). 
Peak 6-Hour Rainfall vs. Number of Debris-Flow Reports, Kaluanui Study Area

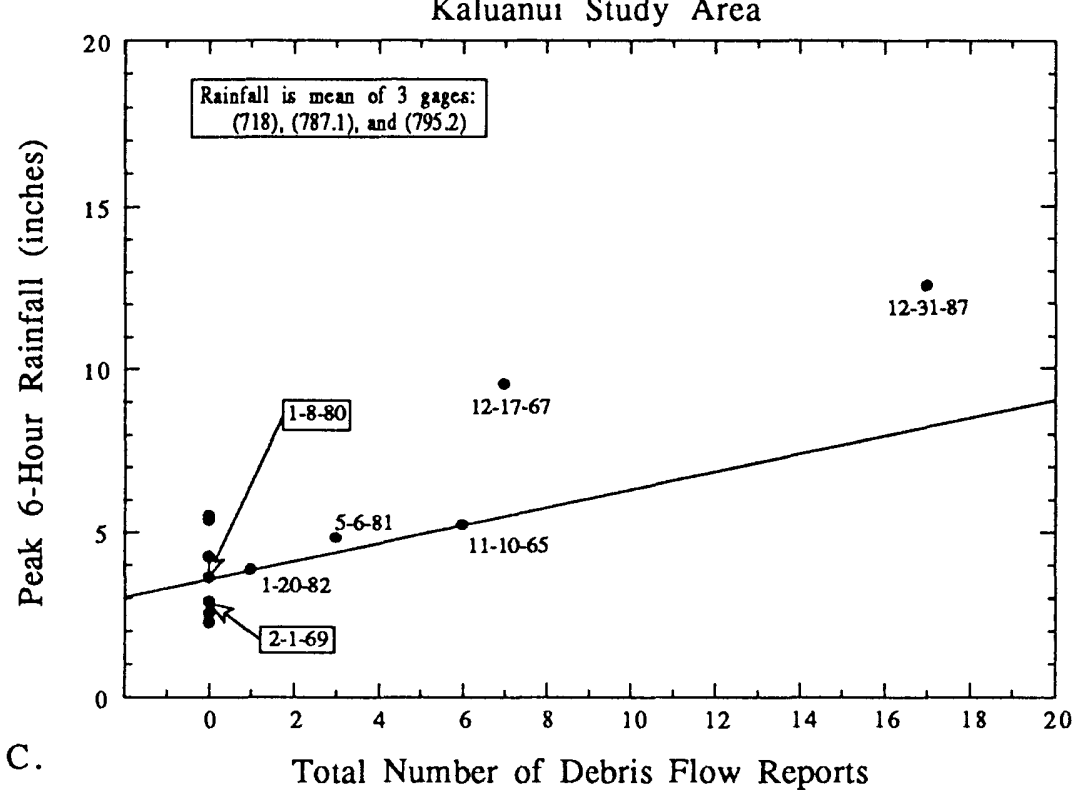

Figure 11C. Peak six hour rainfall versus the number of debris flow reports for historical storms in the Kaluanui study area (see table 6 and figure 5).

Rainfall/Debris-Flow Thresholds for Kaluanui Study Area

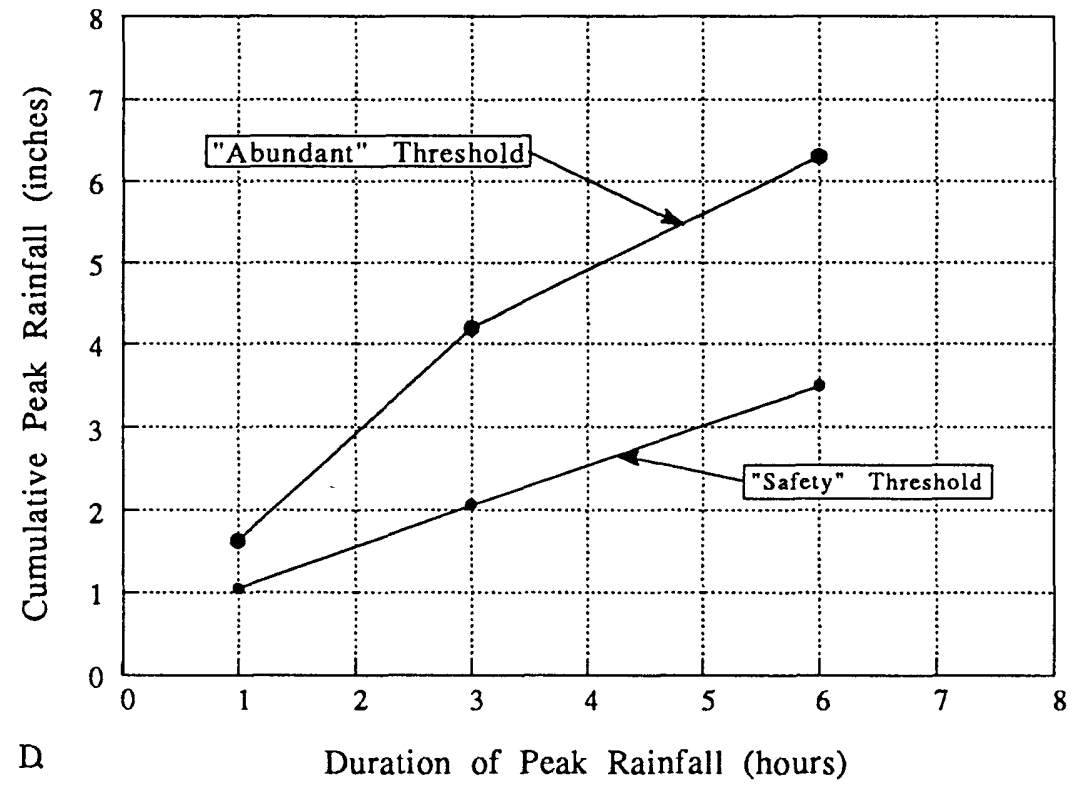

Figure 11D. Rainfall warning thresholds for the initiation of debris flows in the Kaluanui study area, derived from the historical data plotted above. (See text for explanation of derivation and use of "Abundant" and "Safety" thresholds.) 